\title{
Respirable nano-particulate generations and their pathogenesis in mining workplaces: a review
}

\author{
Long $\operatorname{Fan}^{1} \cdot$ Shimin $\operatorname{Liu}^{1}$ (D)
}

Received: 31 August 2020/Revised: 24 December 2020/Accepted: 21 January 2021/Published online: 11 February 2021

(C) The Author(s) 2021

\begin{abstract}
There is a growing concern in mining community about the contribution of nano-particulates to miner's health. Despite the health influence of respirable dusts and associated lung diseases have been recognized for decades in the mining industry, the nano-scale particulates accompanying with complicated physiochemical properties and their enormous contribution in quantity have been drawing attentions only in recent a few years because of the advancement of nanoscience discipline. In this review, we examine the current regulations of dusts exposure and the dominant mass-based monitoring methods to point out the ignorance of nano-particulates in mining industry. The recognized mining-related nano-particulates sources are summarized to identify the mechanically generated finer particulates including particles and aerosols. In addition, the mechanism of adverse health impact on miner with exposure to nano-scale particulates is discussed in a detail to emphasize their substantial detriment as a potential respiratory hazard. Characterization of the complex physiochemical properties of nano-particulates are then summarized and discussed because these properties could be different from regular respirable dusts due to their dramatically increased surface area and particulate counts. The intent of this review is to demonstrate the potential of adverse health effect of nano-particulate on the mine personals throughout the mining cycle and to identify the research gaps of the mine nano-particulate characterization and quantification. We suggest that further understanding of the mining induced nano-particulate properties and their pathogenesis are critical for the future engineering control measure to mitigate the potential health threat for future miners.
\end{abstract}

Keywords Nano-particulate $\cdot$ Lung diseases $\cdot$ Generation sources $\cdot$ Nano-scale characterization

\section{Introduction and background}

Dust can be broadly defined as small solid particles resulting from the breakage of solids. The adverse health impact of dust exposure for miners during operation has been recognized as a paramount issue in mining industry since early 1900s (NIOSH 2019). Sufficient proofs have been studied about their relationship with lung diseases (Cohen et al. 2016; Blackley et al. 2018; Doney et al. 2019;

Shimin Liu

szl3@psu.edu

1 Department of Energy and Mineral Engineering, G3 Center and EMS Energy Institute, The Pennsylvania State University, University Park, PA 16802, USA
Moreno et al. 2019). When suspended in air, smaller airborne particles of dust can be a great risk to the miners' respirable system. It has been proved that the smaller the aerodynamic diameter of the inhaled dust particle, the more likely it will be deposited more deeply in the respirable tract (Prata 2018; Gasparotto et al. 2018; Gianoncelli et al. 2018; Entwistle et al. 2019; Graczyk and Riediker 2019). A dramatic increase of the prevalence of progressive massive fibrosis among working underground coal miners in central Appalachia has been observed in the past decade although stringent regulations have been proposed by MSHA and NIOSH, as shown in Fig. 1 (Blackley et al. 2018; Doney et al. 2019; Hall et al. 2019). The 2018 National Academic of Sciences (NAS) report about mine dust explosion indicted that changes in mining practices, conditions, and 


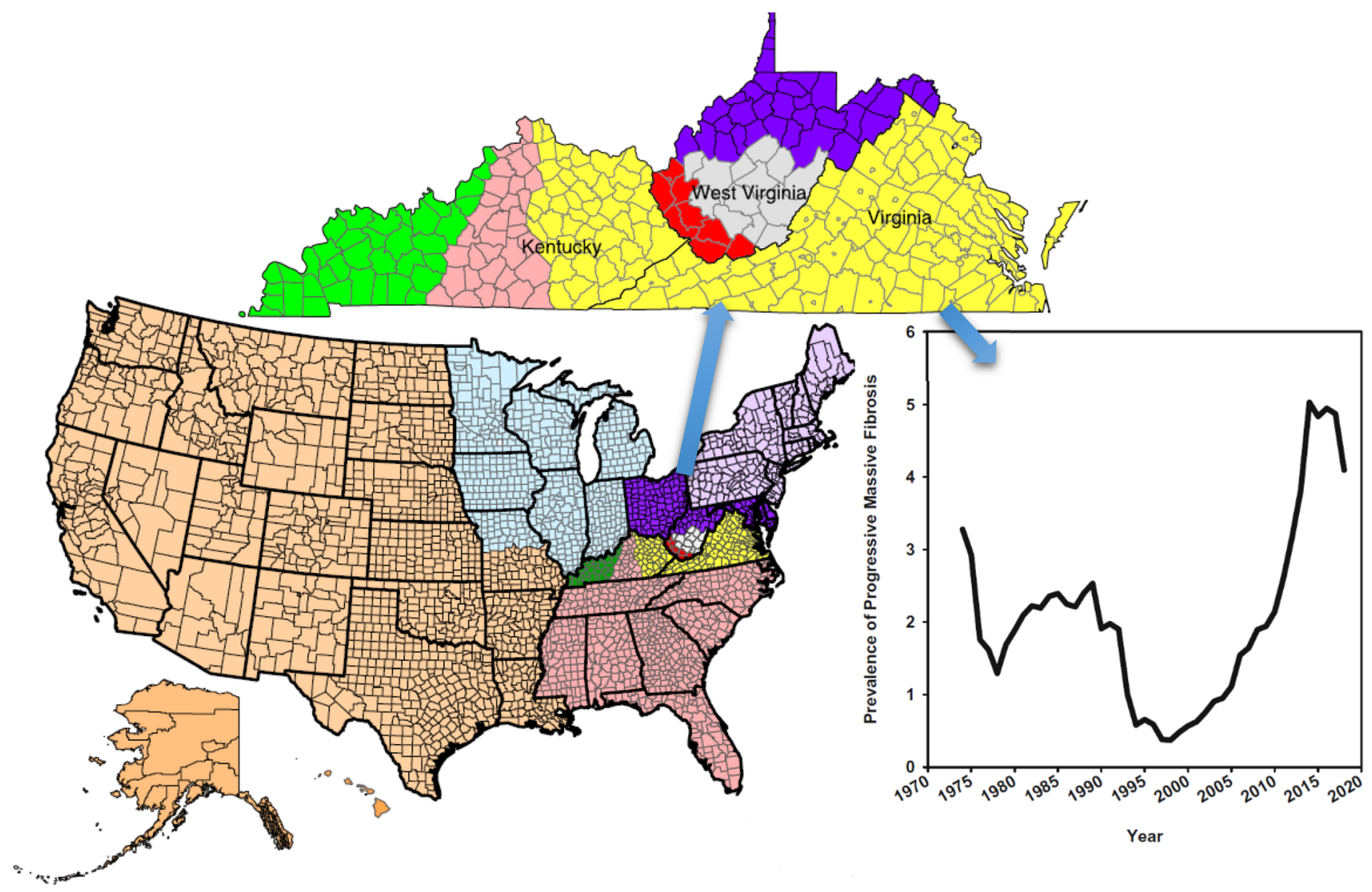

Fig. 1 Prevalence of progressive massive fibrosis among working underground coal miners from 1970 to 2020 in central Appalachia. Central Appalachia includes Kentucky, Virginia, and West Virginia. Different colors in the map represent various coal mine districts from Mine Safety and Health Administration (MSHA). The data are from the Coal Workers' Health Surveillance Program, presenting as the 5-year moving average percentage. (After Hall et al. 2019; Doney et al. 2019)

technologies during the past decades might have led the changes of the typical dust-size distribution of both silica and coal dusts, which could result in the changes of disease epidemiology (Coal et al. 2018). Comprehensive investigation of the new challenges related to dusts monitoring, distribution and characterization were recommended. Throughout the international communities, occupational exposure limits (OELs) have been established to provide the guidance on hazardous airborne contaminant concentrations that mine workers can be exposed to during their working lifetime by various global organizations, including United State National Institute for Occupational Safety and Health (NIOSH 2011), Australia Queensland Government, Organization for Economic Co-operation and Development (OECD 2017), International Organization for Standardization (ISO 2014) and several other institutions, organizations and governmental agencies. In the mining industry, there are two types of primary dusts during the extraction and processing: respirable mine dust (RMD) and silica dust (generally referring to the rock particle with quarts concentration of more than 5\%). Specifically, for the coal mining, the respirable mine dusts are termed as respirable coal mine dusts (RCMDs). The different compositions in coal dust as well as its byproducts (e.g. nitrogen dioxide, sulphur dioxide, ash and soot) and waste are considered serious exposure hazards for mine workers due to their mobilization and bioaccumulation in human tissues and toxic effect, which can induce DNA damage in different organisms, indicating the need for biomonitoring (KabataPendias 2000; Menezes et al. 2013; Menezes et al. 2015). Sufficient proofs have been studied about their relationship with lung diseases.

The proposed and recommended OELs for mining industry are listed in Table 1 by various mining countries. The OELs of RCMD range from $1 \mathrm{mg} / \mathrm{m}^{3}$ to $6 \mathrm{mg} / \mathrm{m}^{3}$, while OELs of silica dusts from $0.1 \mathrm{mg} / \mathrm{m}^{3}$ to $20 \mathrm{mg} / \mathrm{m}^{3}$. These OELs are measured by a gravimetric sampling method with airborne particles filter collection. Mass concentration is used for these countries to assess the OELs that they believe the workers can be exposed during a certain time period at the low risk of adverse health effects.

It is commonly believed that dust size is critical for the assessment of the adverse effect on human health. Only dust particle with a smaller diameter can become 
Table 1 Dust and DPM exposure monitoring and sampling approaches (by countries) (Bocskor et al. 2017)

\begin{tabular}{|c|c|c|c|c|c|c|c|}
\hline \multirow[t]{2}{*}{ Country } & \multicolumn{2}{|c|}{$\begin{array}{l}\text { Total production } \\
\text { in } 2015\end{array}$} & \multicolumn{2}{|c|}{ Underground mining } & \multirow[t]{2}{*}{ Dust/DPM exposure limits } & \multirow{2}{*}{$\begin{array}{l}\text { Required } \\
\text { monitoring } \\
\text { devices }\end{array}$} & \multirow[t]{2}{*}{$\begin{array}{l}\text { Sampling } \\
\text { methods }\end{array}$} \\
\hline & Rank & $\begin{array}{l}\text { Thousand } \\
\text { short tons }\end{array}$ & $\begin{array}{l}\text { Est. } \\
\text { percent of } \\
\text { total } \\
\text { production } \\
(\%)\end{array}$ & $\begin{array}{l}\text { Typical } \\
\text { method }\end{array}$ & & & \\
\hline $\begin{array}{l}\text { People's } \\
\text { Republic } \\
\text { of China }\end{array}$ & 1 & $4,376,984$ & 90 & Longwall & $\begin{array}{l}\text { Depending on a silica content ranging from } \\
5 \% \text { to } 50 \% \text {, exposure limits are between } 6 \\
\text { and } 1 \mathrm{mg} / \mathrm{m}^{3} \text { for RCMD and between } 20 \\
\text { and } 2 \mathrm{mg} / \mathrm{m}^{3} \text { for total coal mine dust }\end{array}$ & $\begin{array}{l}\text { Personal } \\
\text { gravimetric } \\
\text { sampler }\end{array}$ & $\begin{array}{l}\text { Gravimetric } \\
\text { method }\end{array}$ \\
\hline $\begin{array}{l}\text { United } \\
\text { States }\end{array}$ & 2 & 896,941 & 34 & $\begin{array}{l}\text { Room- } \\
\text { and- } \\
\text { pillar, } \\
\text { longwall }\end{array}$ & $\begin{array}{l}\text { RCMD exposure limit is } 1.5 \mathrm{mg} / \mathrm{m}^{3} \text {. Quartz } \\
\text { exposure limit is } 0.10 \mathrm{mg} / \mathrm{m}^{3} \text {. DPM } \\
\text { exposure limit: } 0.16 \mathrm{mg} / \mathrm{m}^{3} \text { (measured as } \\
\text { TC) }\end{array}$ & $\begin{array}{l}\text { Personal } \\
\text { gravimetric } \\
\text { sampler }\end{array}$ & $\begin{array}{c}\text { Gravimetric } \\
\text { method }\end{array}$ \\
\hline India & 3 & 643,720 & 10 & $\begin{array}{l}\text { Room- } \\
\text { and- } \\
\text { pillar, } \\
\text { longwall }\end{array}$ & $\begin{array}{l}\text { RCMD exposure limit is } 2 \mathrm{mg} / \mathrm{m}^{3} \text {, when the } \\
\text { silica content is less than } 5 \% \text {. When the } \\
\text { silica concentration is } 5 \% \text { or more, the } \\
\text { exposure limit is calculated as } 10 \text { divided } \\
\text { by the percent silica content in the RCMD }\end{array}$ & $\begin{array}{l}\text { Monitoring } \\
\text { device } \\
\text { approved by } \\
\text { the Indian } \\
\text { government }\end{array}$ & $\begin{array}{c}\text { Gravimetric } \\
\text { method }\end{array}$ \\
\hline \multirow[t]{2}{*}{ Australia } & 4 & 560,714 & 20 & Longwall & $\begin{array}{l}\text { New South Wales: Exposure limits is } 1.5 \mathrm{mg} \text { / } \\
\mathrm{m}^{3} \text { (effective on Feb } 1,2021 \text { ) for } \mathrm{RCMD} \\
0.05 \mathrm{mg} / \mathrm{m}^{3} \text { for quartz, and } 0.1 \mathrm{mg} / \mathrm{m}^{3} \\
\text { (effective on Feb } 1,2021 \text { ) for DPM }\end{array}$ & $\begin{array}{l}\text { Personal } \\
\text { gravimetric } \\
\text { sampler }\end{array}$ & $\begin{array}{l}\text { Gravimetric } \\
\text { method }\end{array}$ \\
\hline & & & & & $\begin{array}{l}\text { Queensland: Exposure limits is } 3 \mathrm{mg} / \mathrm{m}^{3} \text { for } \\
\text { RCMD with a quartz content less than } 5 \% \text {, } \\
10 \mathrm{mg} / \mathrm{m}^{3} \text { for the inhalable fraction, and } \\
0.10 \mathrm{mg} / \mathrm{m}^{3} \text { for quartz }\end{array}$ & $\begin{array}{l}\text { Personal } \\
\text { gravimetric } \\
\text { sampler }\end{array}$ & $\begin{array}{l}\text { Gravimetric } \\
\text { method }\end{array}$ \\
\hline $\begin{array}{l}\text { Republic of } \\
\text { South } \\
\text { Africa }\end{array}$ & 7 & 256,876 & 50 & $\begin{array}{l}\text { Room- } \\
\text { and- } \\
\text { pillar, } \\
\text { some } \\
\text { longwall }\end{array}$ & $\begin{array}{l}\text { Exposure limit is } 2 \mathrm{mg} / \mathrm{m}^{3} \text { for RCMD with a } \\
\text { quartz content less than } 5 \% \text {. If the quartz } \\
\text { content is greater than } 5 \% \text {, an exposure } \\
\text { limit for quartz is } 0.1 \mathrm{mg} / \mathrm{m}^{3}\end{array}$ & $\begin{array}{l}\text { Personal } \\
\text { gravimetric } \\
\text { sampler }\end{array}$ & $\begin{array}{l}\text { Gravimetric } \\
\text { method }\end{array}$ \\
\hline Germany & 8 & 203,613 & 3 & Longwall & $\begin{array}{l}\text { Limiting cumulative exposure for a 2-year, } \\
\text { 220-shift exposure would be an estimated } \\
\text { dose accumulated from an average } \\
\text { exposure of } 4.0 \mathrm{mg} / \mathrm{m}^{3} \text {. DPM exposure } \\
\text { limit: } 0.1 \mathrm{mg} / \mathrm{m}^{3} \text { for general surface } \\
\text { working place and } 0.3 \mathrm{mg} / \mathrm{m}^{3} \text { for } \\
\text { underground non-coal mines }\end{array}$ & $\begin{array}{l}\text { Area gravimetric } \\
\text { sampler }\end{array}$ & $\begin{array}{l}\text { Gravimetric } \\
\text { method } \\
\text { Does based } \\
\text { method }\end{array}$ \\
\hline Poland & 9 & 149,147 & 53 & Longwall & $\begin{array}{l}\text { Exposure limits is } 1 \mathrm{mg} / \mathrm{m}^{3} \text { for RCMD } \\
\text { containing free crystalline silica from } 2 \text { to } \\
50 \%, 4 \mathrm{mg} / \mathrm{m}^{3} \text { for total dust }\end{array}$ & $\begin{array}{l}\text { Personal } \\
\quad \text { gravimetric } \\
\text { sampler }\end{array}$ & $\begin{array}{c}\text { Gravimetric } \\
\text { method }\end{array}$ \\
\hline
\end{tabular}

suspended in the air stream for a long period of time which pose a great risk to the respiratory system with continuous inhaled. Particles ranging from $\sim 60 \mu \mathrm{m}$ to $\sim 2000 \mu \mathrm{m}$ can only reach heights up to approximately 3 feet above the ground surface, while particles with a diameter less than $60 \mu \mathrm{m}$ can be suspended in air for long periods of time (NIOSH 2019). Therefore, by quantifying the mass concentration of dust particles smaller than $60 \mu \mathrm{m}$ has been widely applied in mining industry to assess the severity of dust hazards to miners' health with a strong assumption that dust particles with various diameters cause a same risk of adverse health effects on workers. In fact, it is a really wide sized range for the dusts less than $60 \mu \mathrm{m}$, and the sizedependent health effect should be paid more attention for future characterization and pathogenesis of dusts on miners' respirable system.

In recent years, nano-dust and their aggregates or agglomerates (NOAA) have obtained significant attention 
due to their potential influence on health in work environment. The studies have indicated that nano-scale particles pose a higher risk of human health due to their specific characterizations, such as highly developed surface area per unit weight or volume, which may cause a larger lung deposited surface area (LDSA) with a different toxicology compared to the same mass concentration of dust with relatively large size (Arias-Andres et al. 2018; Johnson et al. 2019; Zhao et al. 2019). The definition of the nanoscale, given by International Organization for Standardization (ISO) and European Committee for Standardization (CEN), is a size range from approximately 1 to $100 \mathrm{~nm}$ (Definition of a nanomaterial) (Commission 2017). A related term, ultrafine particles (UFPs) was also introduced in 2013 Health Eating Index (HEI), referring the fraction of ambient particulate matter $\left(\mathrm{PM}_{0.1}\right)$, containing airborne particles of nanoscale size with a diameter less than $0.1 \mu \mathrm{m}$. At the active mine extraction sites or the processing plants, the continuously coal/rock cutting and breakage can produce a wide range of dust particles including nano-sized dusts (Sarver 2018). These nanosized dusts existing in mining environment throw into a question that the current OELs in assessing dust hazard using a mass concentration instead of a number concentration. Because the total mass of the nanoparticles contained in the aerosol may constitute only its percentage, but their number can reach over $80 \%$ of the total particles (Oberbek 2019). A better understanding of the formation, transformation, and adverse health impacts of nano-scale dusts would contribute to the protection of miners' health and future regulation formulation.

This review tries to summarize the state of knowledge on the evidence of nano-dust hazards in mining industry and their fate and effects in organisms after inhalation by discussing existing literatures regarding nano-dust characterization. Five sections address exposure, health effects, and characterizations in the following order: (1) current regulations; (2) health impacts of nano-scale dusts; (3) Mining related nano-dust sources; (4) surface characterization and size distribution; and (5) coating effect with DPM.

\section{Potential sources throughout the mining cycles and the nano-dust fraction}

\subsection{Potential dust sources for the completed mining cycle}

In mining operations, no matter surface or underground mining (Fan and Liu 2019a, b), dust is generated in obvious ways. Anytime an operation is cutting, blasting, transporting, refining, or processing a dry material, there is a great likelihood that dusts can be generated (Fan and Liu 2017; NIOSH 2019; Zhao et al. 2020). The dust generated will easily be liberated into the confined working environment, forming a dust cloud if its concentration is high and with proper sizes. This type of dust cloud, obviously, is a great health threat to mining operation personnel. In addition, high dust levels can impede visibility and thus directly affect the safety of workers. In most cases, however, exposure to dust clouds can be prevented through administrative controls (such as increasing waiting time before getting access to the operational regions) and engineering controls (such as suppression and prevention from water sprays), because large-size particulates $(60-2000 \mu \mathrm{m})$ only can suspend in the air for a very short time before settling down on the ground according to EPA (1996). Therefore, these dusts generally have been mitigated before interacting with workers. Particulates with size less than $60 \mu \mathrm{m}$ can suspend in the air for a long time before creeping down. It is expected that the smaller the dust size is, the longer suspending time for the corresponding dusts. Therefore, nano-dusts can easily suspend in the air for hours and be transmitted to locations far away from its original sources. The possible mining related nanodust sources are summarized in Fig. 2. Proofs of existence of nano-dusts in mining related operations have been reported.

Drilling and blasting are the two primary mining operations involving displacement of air around the operational regions. Both are notorious sources of nano-dusts with the fragmentation of the rocks. Surface mine drilling is accomplished using both rotary and percussion drilling methods. In particular, dry drilling achieves penetration through rock and cleanness of cuttings using pneumatic power. Fines particulates will be delivered to the air around the drill holes and become a risk of dust exposure. Generally, wet drilling by using moisture air and installing shroud around the drill are the primary dust control methods applied in fields. However, the water suppression effect with nano-sized particulate and the leakage between the shroud and complicated working surfaces are still skeptical by researchers (Zimmer et al. 1987; Organiscak and Page 2005). Droplet size is critical in dust suppression. Only with the size similar to the size of nano-particulate, the water spray system can be applied with a high efficiency. There are two difficulties for the water suppression of nano-particulates: the formation of nano-scale droplets and the polydisperse of size distribution. While blasting seemingly generates large amount of dust, the operation occurs infrequently enough that it is not considered to be a significant contributor to particulate less than $10 \mu \mathrm{m}$ (Muleski 1991; Richards and Brozell 2001). The investigation of the dust size distribution for both soot and minerals with primary blasting in limestone quarries well 


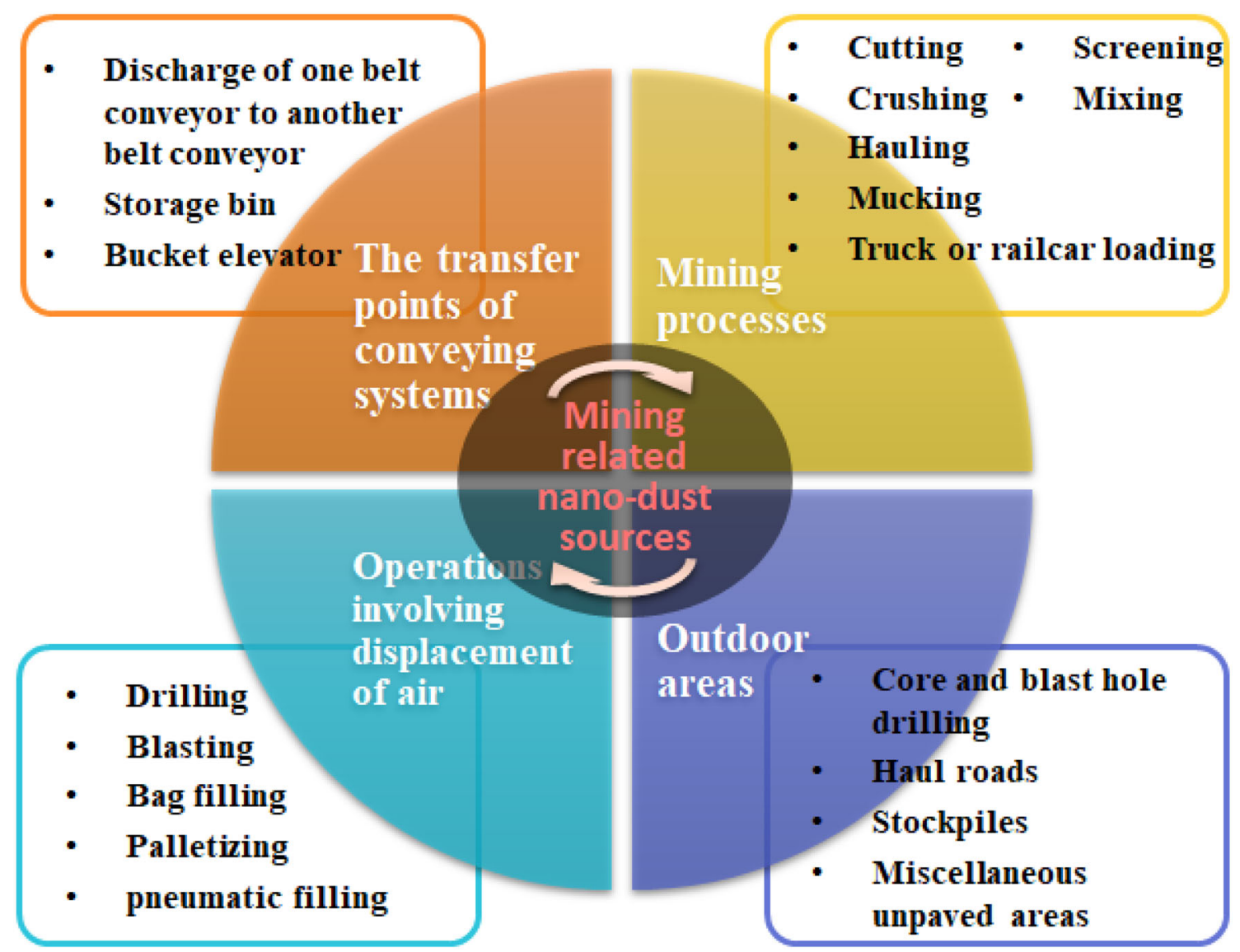

Fig. 2 Mining related nano-dust sources

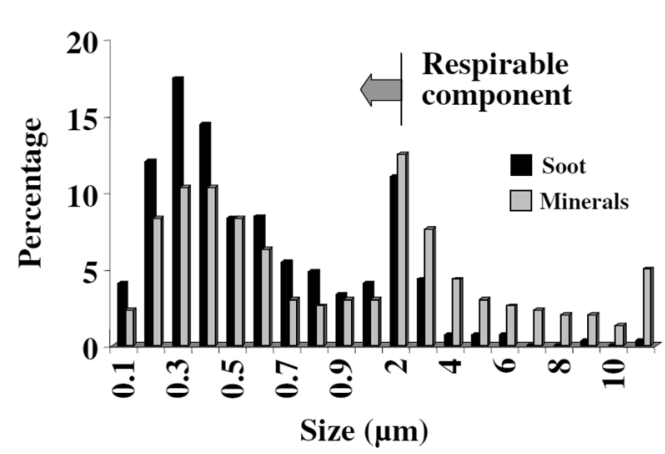

(a) Quarry samples

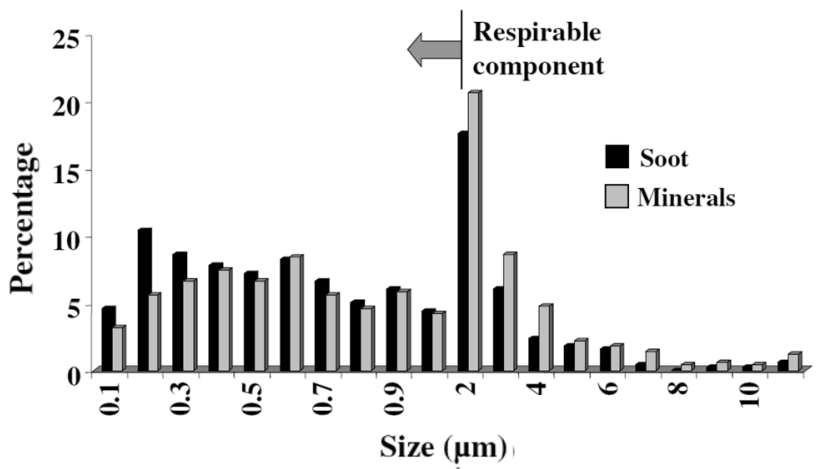

(b) Morgantown samples

Fig. 3 Size distributions of soot and minerals from quarry $\mathbf{a}$ and Morgantown $\mathbf{b}$ samples. Ten random, low-resolution, images were taken of each filter, and all particles on these images measured by image analysis. The peak seen at 2.0 is an artefact of changing the histogram bins from $0.2 \mathrm{~mm}$ to $2.0 \mathrm{~mm}$ at this point on the axis (Jones et al. 2003)

demonstrated the existence of nano-scale dusts (Jones et al. 2003). The image analysis-based quantity percentage is shown in Fig. 3. Although underground blasting is confined in an enclosed environment, setting off the blast in underground operations generally occurs off-shift when miners are evacuated, and ventilation is used to clear the mine for hours. There is less likelihood for dusts accumulation under this circumstance, but secondary dust sources should be paid more attentions, such as the following loading and hauling operations. In addition, mineral 


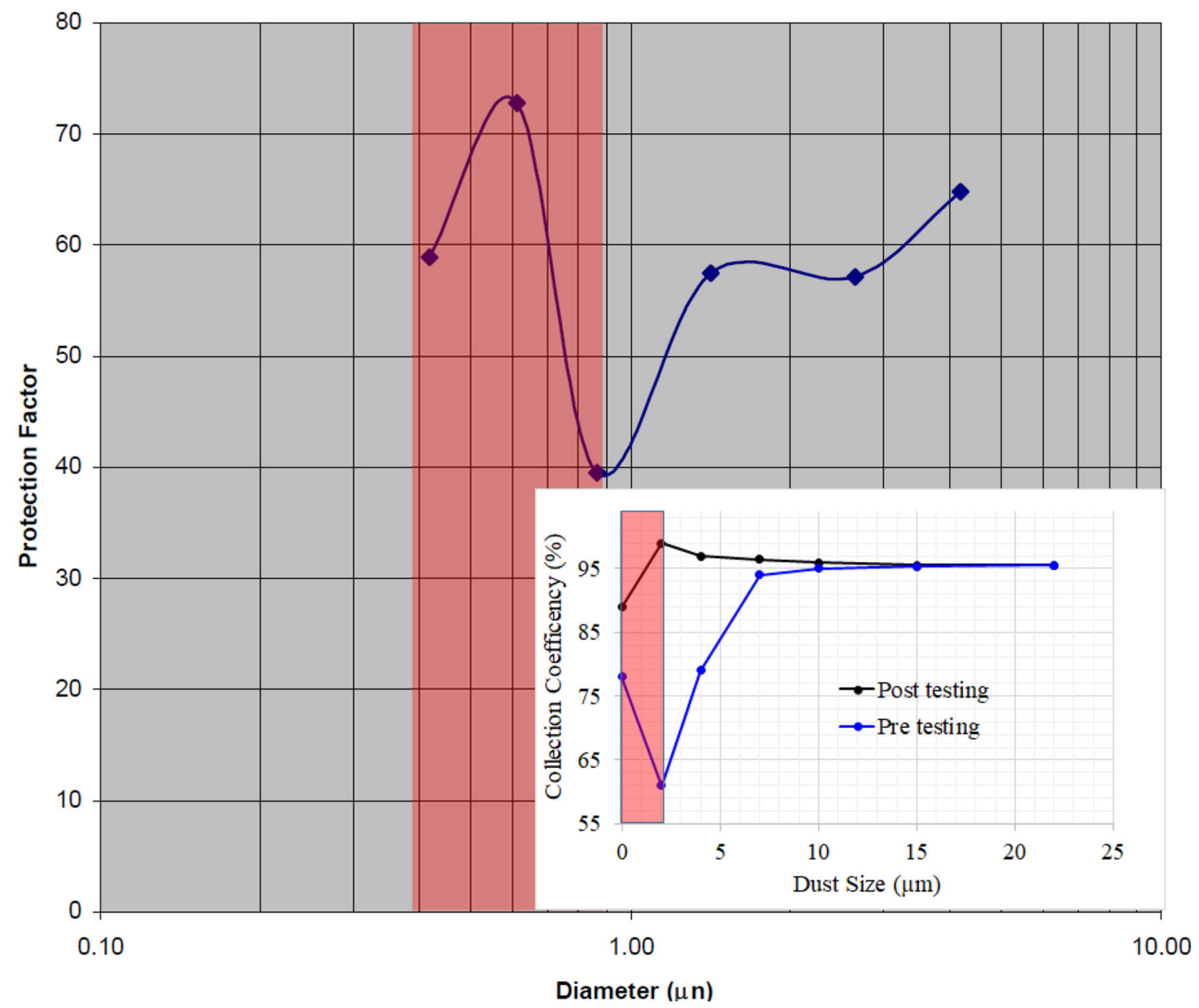

Fig. 4 High protection factors and limited improvement in cab collection efficiency for nano-dusts (After Cecala et al. 1994)

processing on surfaces with pneumatic powers (e.g. bag filling) can also be the potential nano-dust sources because of the continuous air blowing around dust sources. The root causes for the airborne dusts with these processes are that small particles of insufficient weight are picked up by excessive air currents. Generally, dust collection system should be properly designed, and PPEs are suggested for workers within these processes to reduce inhaled respirable dusts.

Mining processes such as cutting, crushing, mucking, hauling and so on are primarily related to the breakup and transport of rock blocks, where new dusts formed due to mechanical forces or existing dusts become airborne due to disturbances. The mechanical breakup forms dusts due to the inherent nature of size-reduction and segregation processes. Relative dust emission rates are different from different mineral processing equipment. The general principle summarized, as one would expect, is that emissions increase as the size of the material processed decreases. It is recommended that the readers can refer EPA-estimated particulate emissions for crushed stone operations for more data. Worker exposure may be managed through engineering controls to coat, suppress, or enclose the dust sources, or by isolating the worker from the dust sources. However, it was evident that the improvement in cab collection efficiency is limited for nano-scale dusts and more protection should be focused on the nano-scale dusts. Figure 4 demonstrates the limited cab collection efficiency for nano-scale dusts as marked in red. Also, the protection factor (the average outside respirable dust concentration divided by the inside cab dust concentration) is high for the nano-scale dusts as measured by GRIMM Particle monitors (Gresh et al. 1994). The potential second dust sources during loading and hauling of "mucks" can liberate existing dusts, which have been attached on the surface of broken rocks, via using LHD (load-haul-dump) vehicles and muckers. Local ventilation and water applications to the muck pile are the primary means of dust control. But for different types of rocks, the dust control effectiveness varies. For example, water suppression cannot be efficiently applied in coal mines due to its hydrophobic nature. Different types and application ratios of additives have 
been studied for suppression and prevention of hydrophobic dusts (Blazek 2003; Organiscak 2013). Details about of this is beyond the scale of this review.

Different types of conveyors can be used in mines for transporting materials, from raw unprocessed ore to fully processed products. A conveyor and its transfer points are well known to generate significant amount of respirable dusts. Fugitive emission is the most common dust source related to material transportation with a conveyor belt. Spillage results from uncontained or improperly loaded material, and carryback comes from materials falling to discharge from the belt as it is transferred or discharged from the conveyor belt, can become airborne via interacting with the ventilation airflow currents (NIOSH 2019). Proper design and selection of the conveyor equipment accompanying with the enclosed system by considering the transfer distance, property of materials to be transferred, can effectively control the dusts emission towards the working environment. In addition, more attentions should be put on the transfer points, where sufficient airborne dusts can be generated due to the air induction resulting from the materials falling through air, which imparts momentum to the surrounding air. Due to this energy transfer, a stream of air always travels with the falling material and the excessive airflow can pick up the dusts of insufficient weight and make it suspend in air for a long time. The same mechanism of dusts generation in the storage bin, bucket elevator, and other processes where material falling occurs. Combination use of water prevention and suppression systems before, during and after the transfer point is critical to reduce airborne dusts during these processes.

Open areas with exposed product are another dust source in mining process and around surface plants. Stockpiles are the most common region generating dust cloud in a large scale during the material loading, moving and unloading from the stockpiles. Wind fence is normally installed to prevent the dust emission and transmission and contain the operation in a relatively enclosed region. Haul road dust emission control is a significant issue at surface sites as well due to the fugitive dust. It is proved that the dust contribution from the haul truck is $78 \%-97 \%$ of total respirable dusts at surface site, which is highly possible to cause overexposure of mine personnel (Cole and Zapert 1995; Amponsah-Dacosta and Annegam 1998; Reed et al. 2001). Rather than a fixed dust source, the mobile vehicles is a moving dust source, which may have an influence with a large scale. Another concern for the dust source from open areas is the unpredicted wind direction and flowrate, which may have a dominant control on the dust emission and its plume. Therefore, the speed control of haul trucks itself should be considered for dust control. Material wetting is also applied to maintain the respirable dusts stick on the ore surfaces and prevent it becoming airborne.

The size distribution could be dramatically different from the mining-related dust sources due to the different break-up mechanisms of rock during the operation (Smith 1986; Jiang et al. 2016; Yang et al. 2020). Although, with current studies, it keeps largely unknown of the nano-scale fraction of dusts formed in various mining cycles and operations, adamant evidences have shown that the nanoscale dusts can exist in all of these operations, and the number fraction of nano-scale dusts could possess absolute advantage in the total number quantity. The size distribution of samples of mine dust from 50 coal mines in the 10 MSHA bituminous districts shown that the average weight contribution of dusts under 200 mesh $(<75 \mu \mathrm{m})$ could be $(30 \pm 5) \%$, and the nano-scale dusts among them are believed to have a dominant quantity contribution (Cashdollar 1996; Sapko et al. 2007). An investigation of total

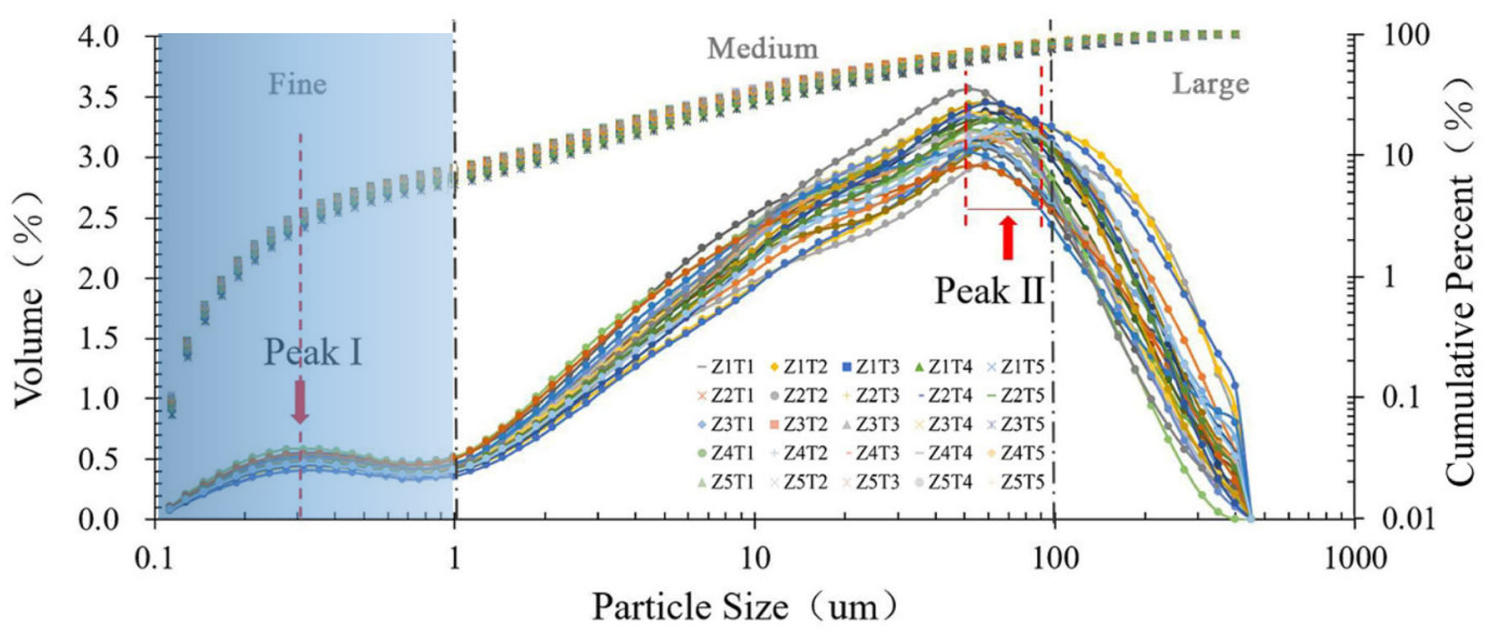

Fig. 5 Size distribution of drilling-induced dusts in the lab with different drilling operations (after Yang et al. 2020) 
suspended particulates in an India surface coal mine revealed that the weight percentages lying within different size ranges were a function of mining activity. The finer dusts would suspend in the air for a longer time and being transported to a further distance. Particle size analysis by Cascade Impactor indicated that at two monitored stations the size range $0-2 \mu \mathrm{m}$ had a weight percentage as high as of $48.2 \%$ and $54.5 \%$ (Ghose and Majee 2007). An example shown in Fig. 5 is the dust size distribution versus volume with various drilling operations measured in the lab by Yang et al. (2020). Different curves represent different drilling operation with various rotation speeds and penetration rates as listed in the table. Two obvious volume peaks occurred for the majority curves, indicating the large volume of dusts with large-scale size of $\sim 100 \mu \mathrm{m}$ and small-scale size of $\sim 500 \mathrm{~nm}$. It is easy to convert this volume percentage to number percentage by assuming the dust shape as a sphere. The number counts of small-scale dusts could be 6 magnitudes larger than that of the largescale dusts. Similar results were also observed in Fig. 7, which sample was collected from an underground mine. The big fraction of the small-scale dusts should be paid more attentions while characterizing the health effects of mining-related dusts rather than only focus on the mass concentration, which is primarily dominant by the largescale dusts in mining industry.

\begin{tabular}{llllll}
\hline Item & $\mathrm{Z} 1$ & $\mathrm{Z} 2$ & $\mathrm{Z} 3$ & $\mathrm{Z} 4$ & $\mathrm{Z} 5$ \\
\hline Rotation $(\mathrm{r} / \mathrm{min})$ & 600 & 900 & 1250 & 1750 & 2600 \\
Item & $\mathrm{T} 1$ & $\mathrm{~T} 2$ & $\mathrm{~T} 3$ & $\mathrm{~T} 4$ & $\mathrm{~T} 5$ \\
Penetration $(\mathrm{mm} / \mathrm{s})$ & 0.75 & 0.85 & 1.0 & 1.2 & 1.5 \\
\hline
\end{tabular}

(a)

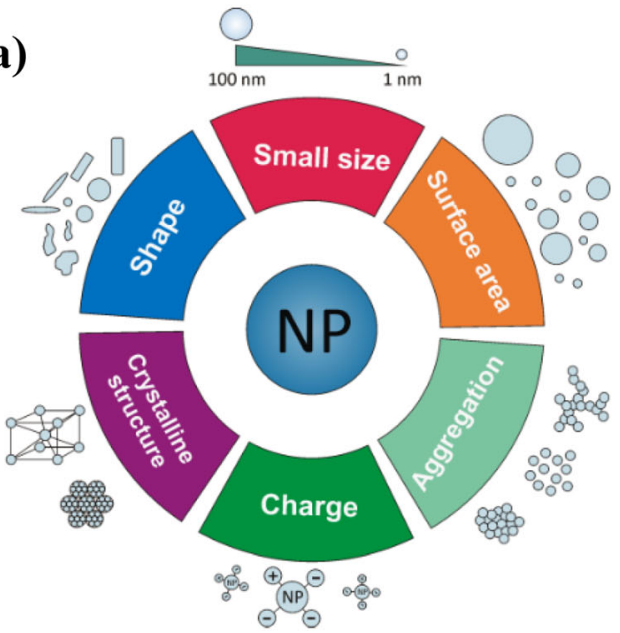

\subsection{Nano-dust fraction and surface characterization}

Numerous factors influence miners' health of exposure to mining-inducted nano-dust. The hazard posed by inhaled nano-dusts in mining industry depends on their abundance and particle sizes, properties such as chemical composition, solubility, shape, and surface area, which all play a role in the associated health effects, as shown in Fig. 6 (Entwistle et al. 2019; Liu and Liu 2020). Surface area of particles can exponentially increase with the decreasing particle size, reflecting the increased physical and chemical activities of nano-particles (Fig. 6b). A schematic represent of a typical dust size distribution of the number concentration, surface area concentration, and mass concentration in underground mines is shown in Fig. 7, indicating that although nanoparticulates contribute a micro fraction of the total mass, their number contribution is significant. Small-scale particulates could suspend in the working environment for a longer time and transmit to a further location with directional airflow in underground. Therefore, these small-scale particulates are highly likely to be inhaled by miners. Dust exposure can span a wide range of particles sizes in mining industry with health effects depending upon the region of deposition in the lung. For this reason, the size distribution of dusts existing in the working environment should be evaluated. Three dust fractions are defined, namely inhalable, thoracic and respirable fractions. There has been international agreement that OELs for dusts should normally be specified as one of the above fractions. The relationship between dust size and its deposition are given by ACGIH in 1999 (Table 2), indicating that the nano-scale dusts are completely respirable and can be fully deposited in the lung or transport into bloodstream. (b)

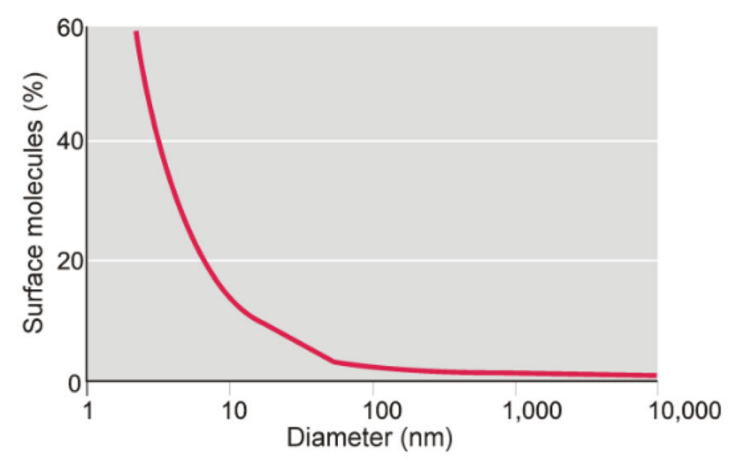

Fig. 6 a Physicochemical properties of nanoparticles. b With the decreasing particle size below $100 \mathrm{~nm}$ the surface molecules exponentially increases (Oberdörster et al. 2005; Čokić 2018) 


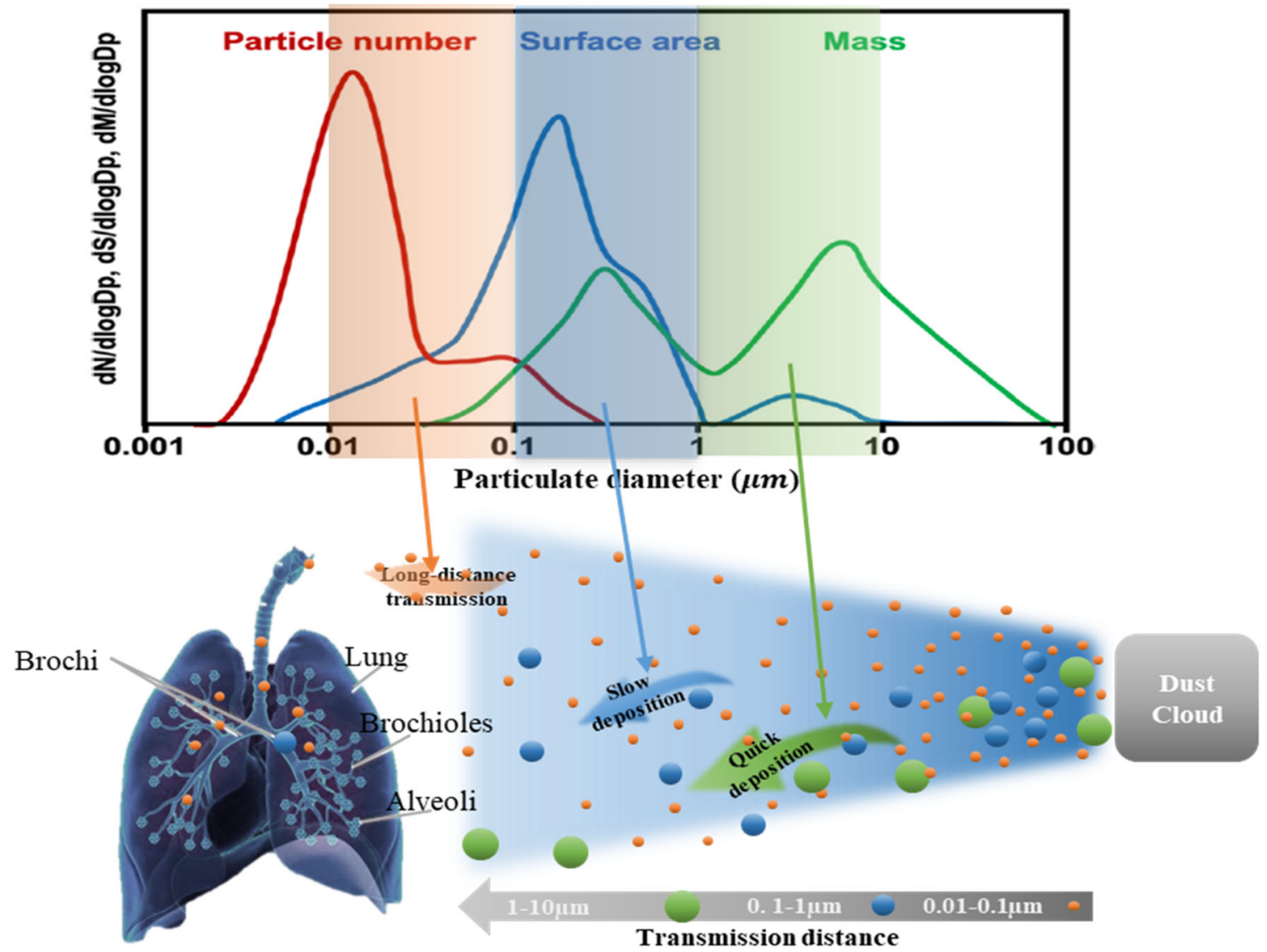

Fig. 7 Particle-size distribution of nano dusts and their transmission distance (After Kwon et al. 2020). dN/dLog $D p$, particle number per cubic millimeter; $\mathrm{d} S / \mathrm{d} \log \mathrm{D} p$, particle surface area per cubic millimeter; and $\mathrm{d} M / \mathrm{d} \log \mathrm{D} p$, particle mass per cubic millimeter, respectively

Table 2 Demonstration of particulates deposition fraction with size (after ACGIH 1999)

\begin{tabular}{llll}
\hline $\begin{array}{l}\text { Aerodynamic } \\
\text { diameter }(\mu \mathrm{m})\end{array}$ & $\begin{array}{l}\text { Inhalable } \\
\text { fraction }(\%)\end{array}$ & $\begin{array}{l}\text { Thoracic } \\
\text { fraction }(\%)\end{array}$ & $\begin{array}{l}\text { Respirable } \\
\text { fraction }(\%)\end{array}$ \\
\hline 0 & 100 & 100 & 100 \\
1 & 97 & - & 97 \\
2 & 94 & 94 & 91 \\
3 & - & - & 74 \\
4 & - & 89 & 50 \\
5 & 87 & - & 30 \\
6 & - & 80.5 & 17 \\
7 & - & - & 9 \\
8 & - & 67 & 5 \\
9 & - & - & - \\
10 & 77 & 50 & 1 \\
\hline
\end{tabular}

With above discussion, a fully characterization of the size less than 1 micro should be focuses on for mining resulted dusts. We can acknowledge the value of mass centration as shown in green curve in Fig. 7, but the pathogenesis study will be benefit much more from the red and blue curves. Establishment of the relation of mass to number and surface area through characterization would be the key to better understand the potential transmission and pathogenesis mechanisms by inhalation of nano-scale dusts.

Numerous techniques have been applied to characterize the dust size distribution, shape and chemical compositions such as SEM-EDX, TEM-EDX, XRD (X-ray Diffraction), DLS (Dynamic Light Scattering), SAXS (Small-angle X-ray Scattering), AFM (Atomic Force Microscopy), FTIR (Infrared Spectroscopy and Atomic Force Macroscopy), etc. Both SEM-EDX and TEM-EDX are equipped with energy dispersion X-ray, allowing the analysis of the mineral composition. They are well established for chemical identification of particles (Kasahara et al. 1993; Kasparian et al. 1998; Carpenter et al. 2002; Deboudt et al. 2010; Cvetković et al. 2012) and determination of size and shape parameters (Kasparian et al. 1998; Wang and Luo 2009). They have been specifically applied to investigate mine dust mineralogy and particle size (Denee 1972; White and DeNee 1972; Huggins and Meyers 1986). Detailed guidance on the use of SEM-EDX for analysis of 
particulate samples is proposed by the US EPA (Environmental Protection Agency) (De 2004). SAXS is an uncomplicated bulk nanostructural quantification technique, particularly sensitive to the smaller end of the nanoscale. It has been reported that the results from SAXS have repeatedly been demonstrated to agree well with findings from electron microscopy. A round robin experiment for inter-laboratory comparison of SAXS results was conducted by Brian et al. (2017). To assess the practical precision and accuracy, indicating that SAXS is a suitable method for revealing particle size distribution in the sub $-20 \mathrm{~nm}$ region (at minimum). Dynamic light scattering is a technique tool to diagnose particle size distribution in solution or colloidal suspensions, where the photon correlation spectroscopy (PCS) was applied to calculate the autocorrelation function and deduce the particle size information. Similar technique such as real-time cloud and aerosol spectrometer (CAS) light-scattering measurements was also applied to characterize the dust cloud using a light-scattering theory for irregular particles- ray tracing with diffraction on facets (RTDF) (Hesse et al. 2009), which is considering diffraction at facet in addition to diffraction at the projected cross section applied in dynamic light scattering, and therefore describes the sizedependence better (Barone et al. 2017). The surface topography and chemical property such as functional groups can be assessed through AFM and FTIR. AFM is powerful tool to investigate the three-dimension surface tomography, friction (Fujihira and Morita 1994; Frisbie and Rozsnyai 1994), magnetism (Martin and Wickramasinghe 1987; DiCarlo and Scheinfein 1992), surface charge (Sugawara et al. 1994; Yoo et al. 1997), rigidity (Maivald et al. 1991; Persch et al. 1993) and capacitance (Neubauer et al. 1996) by moving a tiny probe contacting with the particle surface. FTIR is unique among all the chemical characterization techniques because it is nondestructive and capable of identifying the molecular level chemistry through the identification of the vibrational signatures related to specific types of chemical bonds (Painter et al. 1981; Liu et al. 2016). In addition, and providing important information on molecular structure, especially the chemical functional groups of organic compounds coated on the particle surfaces.

\section{Mechanisms of health impacts of nano-dusts}

After recognizing that the size and particle counts are critical for the characterization of the nano-particulates, we would like to review the influence of these factors on the transmission, deposition and interaction with organ tissues of nano-particulates. Despite occupational improvements within the mining industry, mine dusts, and associated potential toxic elements (PTEs) generating in mining activities, is one such hazard related cause of adverse health effects on mine workers. Understanding the exposure pathways is critical, as is the source, transport pathway, nature of exposure (e.g. duration, activity) and exposure route (i.e. by inhalation, ingestion or dermal/topical adsorption) (Entwistle et al. 2019). Rather than the well-known health effects of accumulated respirable dusts in human lungs, such as diseases of coal worker pneumoconiosis (black lungs), silicosis, chronic obstructive pulmonary diseases, etc., with an accumulative dust mass concentration only in lungs, nano-dusts may have more complicated mechanisms of adverse health effects on human health with its specific characterizations in a ultrasmall scale. A better understanding of the mechanisms that lead to adverse health impacts, toxicity, and evolving biomonitoring of nano-dusts in mining community are pivotal for future understanding of the pathogenesis of the dust on the human lung.

The mechanisms, the efficiency and the pattern of dust deposition in the lung is known to be determined by the aerodynamics and thermodynamics of dust particles from a physical perspective. Apparently, the nano-sized particles can behave in a more complex way as inhaled. Figure 8 demonstrates the fractional deposition of inhaled particles. The particulates of $10-100 \mathrm{~nm}$ are primarily deposited in the alveolar region where the gas exchange occurs. Rather than only interact with lung cells, nano-sized dusts are of particular concern as they may translocate and be transported by mechanism such as macrophage-mediated clearance (Kreyling 1990; Kreyling et al. 2012), interstitial-lymphatic clearance (Semmler-Behnke et al. 2014) and the blood circulation (Kreyling et al. 2017; Graczyk and Riediker 2019) to distance sites and organs. The predominant mechanism for dust clearance from peripheral lungs is uptake by lung surface macrophages and transport to the larynx. Varying amounts of circulated nano-dusts in human body can be excreted quickly by different routes, usually through the liver, kidney or gastrointestinal tract, and sometimes in sweat, skin cells and hair loss (Baker 2012). However, the deposited nano-dusts can be a potential hazard for human health. Therefore, a much broader list of human diseases can be influenced by inhaled nano-dusts, including cardiovascular, respiratory, liver, neurological, gastro-intestinal, kidney and mental health (Stewart and Hursthouse 2018). In addition, mining-induced dusts can be troublesome on impact with the skin and eyes. Under certain conditions in certain mine locations considerable irritation due to the facial impaction of coarse particles has been reported (Gibson and Vincent 1980; Sun et al. 2007). However, few studies have investigated the impacts of nano-scale dusts. The limited researches conducted in the lab indicates that the small-scale coal dust explore plays an 

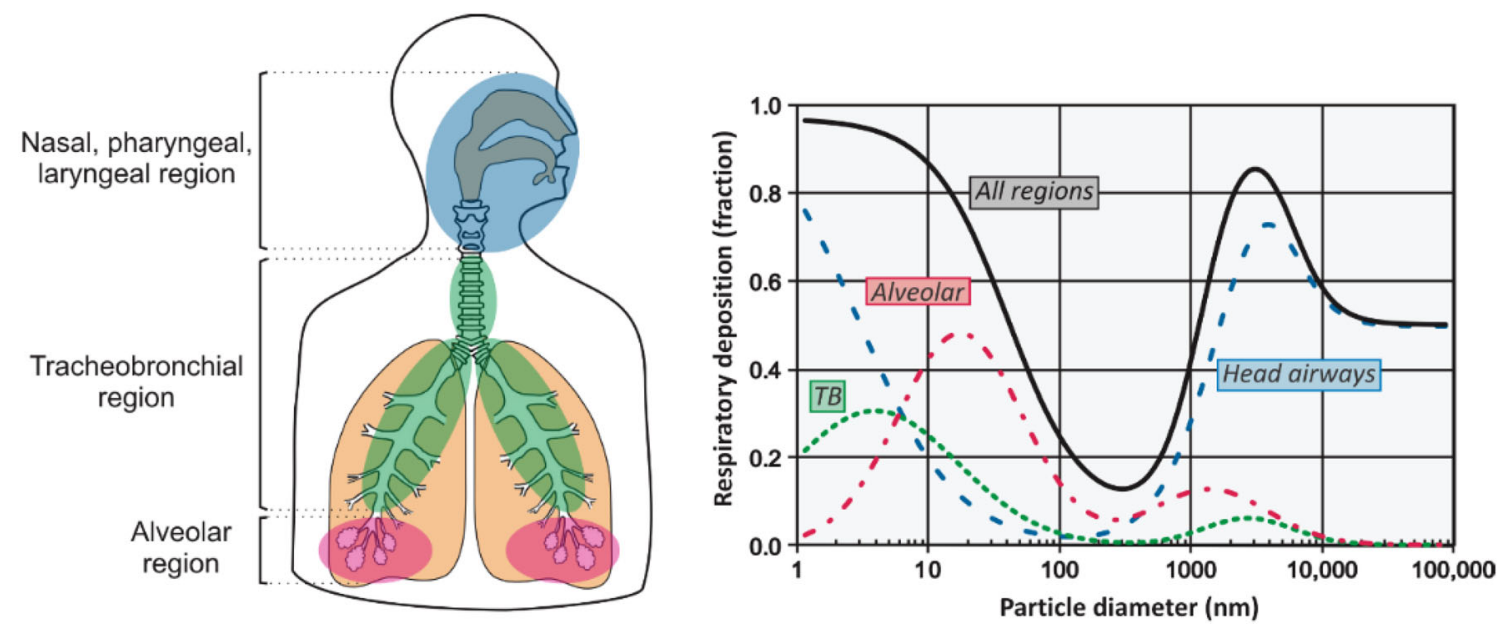

Fig. 8 Predicted fractional deposition of inhaled particles in the nasopharyngeal, tracheobronchial and alveolar region of the human respiratory tract during nose breathing. Based on the data from the international Commission on Radiological Protection (Smith 1994; Čokić 2018)

important role in the development of dry eyes, that were attributed not only to the mechanical injury of coal dust but also its toxicity, which induced the development of xerophthalmia (Sun et al. 2007; 2009). More studies should be conducted focusing on the skin and eyes impact due to nano-scale dusts in the industry working environment.

One noteworthy property of nano-dusts causing attention is their high toxicity and their capacity to bioaccumulate. The continuous inhalation of nano-dusts in the working environment with high dust concentration is hazardous and a silent risk factor to a healthy worker that may lead to oxidative stress, oxidative damage, acute pro-inflammatory response and damage to macromolecules such as lipids (lipid peroxidation), proteins, carbohydrates and nucleic acids (DNA) (Schins and Borm 1999; Silva 2016; León-Mejia et al. 2018). In addition to the well-known lung diseases, liver is reported as a vulnerable target organ since the translocated nano-dust can easily reach micro live vasculature and hepatocytes through bloodstream (Mani 2007; Bourdon et al. 2012; Kim et al. 2014). Biomonitoring tests in the lab demonstrated that Obese rats are more vulnerable to coal-dust inhalation induced adverse health effects, which may induce organ specific pathologies or even aggravate existing diseases where obesity is present (Gasparotto et al. 2018). One group of lung and liver histology comparison with coal dust inhalation has been summarized in Fig. 9, indicating the adverse influence of nano-scale dusts on organ cells. Accumulating evidences suggested that inhaled nano-dusts have a considerable impact on health and disease of the CNS (Central Nervous System) (Block et al. 2012). It is reported that nanoparticles can accumulate in the nasal regions, where they are
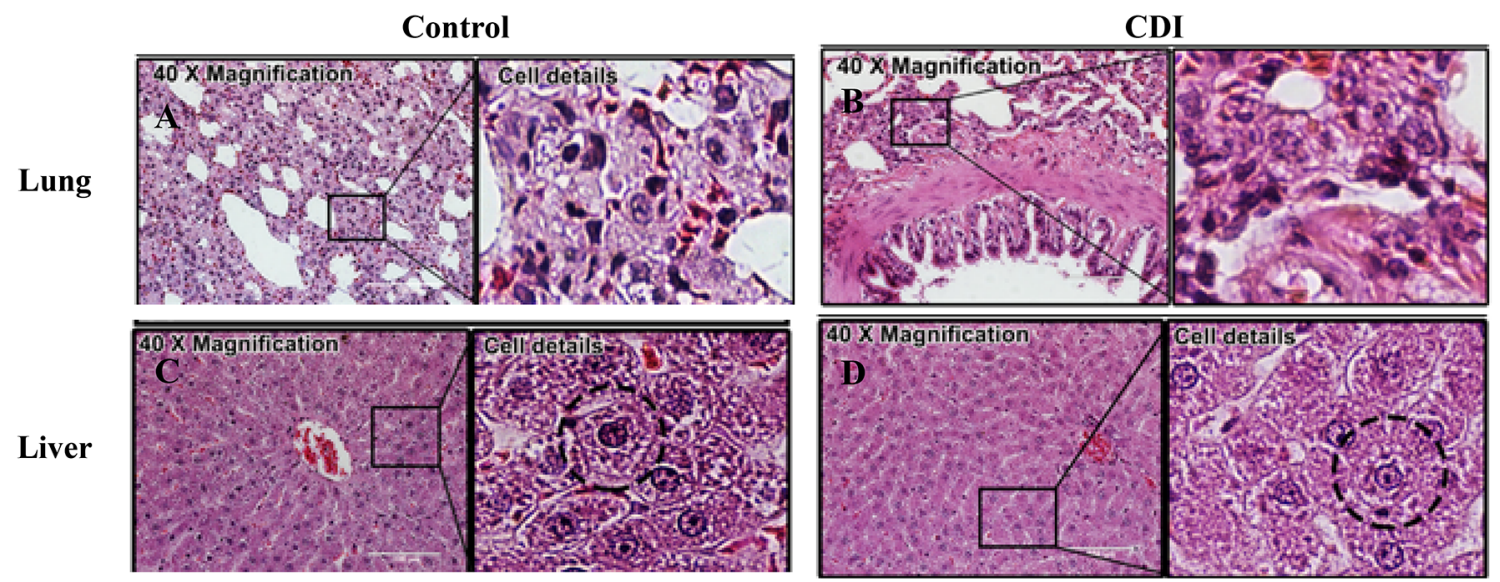

Fig. 9 Lung and liver histology images and oxidative damage. Representative images of a Control (lung), b Coal dust inhalation (CDI) (lung), c Control (liver), d CDI (liver). The liver histologic investigation showed the accumulation of triglycerides in hepatocytes indicating an accentuated hepatic microvesicular steatosis. Animal exposed to CDI gad alterations in their lung structures, where the tissue showed very thin cell layers and severe distensibility. (After Juciano Gasparotto et al. 2018) 
then transported along sensory axons of the olfactory nerve directly to the CNS (Oberdörster et al. 2005; Oberdörster and Elder 2009). Dust exposure has also been associated with autism, attention deficit/hyperactivity disorders and neurodegenerative diseases-although evidence of causation has not been established (Kioumourtzoglou et al. 2015; Casanova et al. 2016; Heusinkveld et al. 2016; Cacciottolo et al. 2017; Liu and Liu 2020).

The toxicity mechanisms are clearly related to chemical and physical compositions of nano-dusts and molecular mechanisms driving the body defense or possible related diseases. The micro particles inside the tissues may undergo complex metabolic transformations and the surface properties can be modified by removal and deposition of chemical elements, metals and salts, or by adsorption of macro-molecules such as proteins (Gianoncelli et al. 2018). Numerical studies of particle characterizations has been reported from different part of the world, as discussed in Sect. 2. However, a very few sparse tests have been reported related to lung tissue chemical analysis by using different technologies, including PIXE (particular-induced X-ray emission), SEM (Scanning Electron Microscopy), TEM-EDS (Transmission Electron Microscopy - Energy Dispersive X-ray Spectroscopy), $\mu$ FTIR (Fourier Transform Infra-Red), SR- $\mu$ XRF (Synchrotron Radiation XRF). The application of PIXE was firstly reported in 1981 by Robaye et al. involving multiple procedures involving freeze-drying (Pascolo et al. 2015), low temperature ashing and dissolution that completely destroys the tissues itself. Then it is improved by Annegarn et al. and widely used in biomonitoring region for dust induced adverse health effects (Annegarn et al. 1988; Ogasawara et al. 2011; Chino et al. 2015; He et al. 2017). It is believed that SEM and TEM have a higher spatial resolution for this purpose, however, they are more feasible for dust characterization because the lower detection sensitivity that limit the information can be obtained from the tissues. Another reason why SRF is proposed for tissue chemical analysis is the relatively easy sample preparation and single particle can be discriminated in the heterogeneous aggregates. Recently, Alessandra et al. applied SR- $\mu$ XRF spectromicroscopy to track the dust inside histological samples of lung tissue and investigate the chemical nature at nanometer spatial resolution. They found XRF can quantify important elements in nano-deposits providing information on the presence of highly toxic material. Using the same technique, Zhang et al. found that the bioavailable iron contained in coal can induce an increment of ferritin in the cells and stimulate lipoperoxidation via free radical production and eventually induce cell death (Ackerman et al. 1999). Similar results obtained by McCunney et al. suggested that the main active compound of coal inducing pneumoconiosis is iron (McCunney et al. 2009). Another advanced imaging technique widely applied is micro Fourier Transform Infra-Red ( $\mu$ FTIR) spectroscopy. Basing on the adsorption of IR radiation by molecules and molecular groups at specific frequency, $\mu$ FTIR approaches are sensitive, label-free and non-damaging analytical tools for the characterization of biomolecules, revealing the vibrational pattern of the investigated samples (Pascolo et al. 2015). The well-known IR adsorption profile of fundamental components of biological tissues such as protein, nucleic, carbohydrates etc. also benefits the application of this technique. The demonstration of results acquired from different techniques are shown in Table 3.

Although various techniques can be applied to quantify the surface composition of nano-scale dusts. Attention to details is required while selecting the proper techniques to quantify the surface toxicity. For instance, both SEM and TEM-EDS are adequate for particulate analysis with specific surface elementals attachment, while $\mu \mathrm{XRF}$ and $\mu$ FTIR can be applied to map the elemental distribution in tissues. Therefore, choosing the proper technique is vital for acquiring accurate surface toxicity of nano-particulates.

\section{Coating effect of nano-particulates with DPM and surface charge}

In mining industry, the materials, in general, have been weathered and subjected to a wide range of environmental conditions that have modified the original ore and gangue materials. In such contexts, the dusts generated are potentially different in their reactivity and hazard from the originally mined sources. Nano-particulates released into the working environment are highly likely to interact with other pollutants, which is also being released in the same environment. An important aspect of nanotoxicity is the modification of physiochemical characteristics of nanoparticulates' surface functionary by coating, aggregating, chemical transforming and more (Lee et al. 2014). Parallels can be drawn with the coal mining industry where changes in specific dust characteristics have been invoked to explain resurgence in diseases such as black lung in the Appalachians (Arnold 2016). As demonstrated in Fig. 10, the nano-particulate or aerosol generally formed by an elemental carbon/silica core accompanying with very complicated surface coatings, including organic carbons species, adsorbed soluble and vaporous hydrocarbons, hydrated sulphates and nitrates, reactive metals and more (Stone et al. 2017).

DPMs (diesel particulate matters) released from diesel powered equipment in underground mining has been identified as a hazard in the past decades. An improved understanding of the physiochemical property change-the interactions between combustion induced aerosols and 


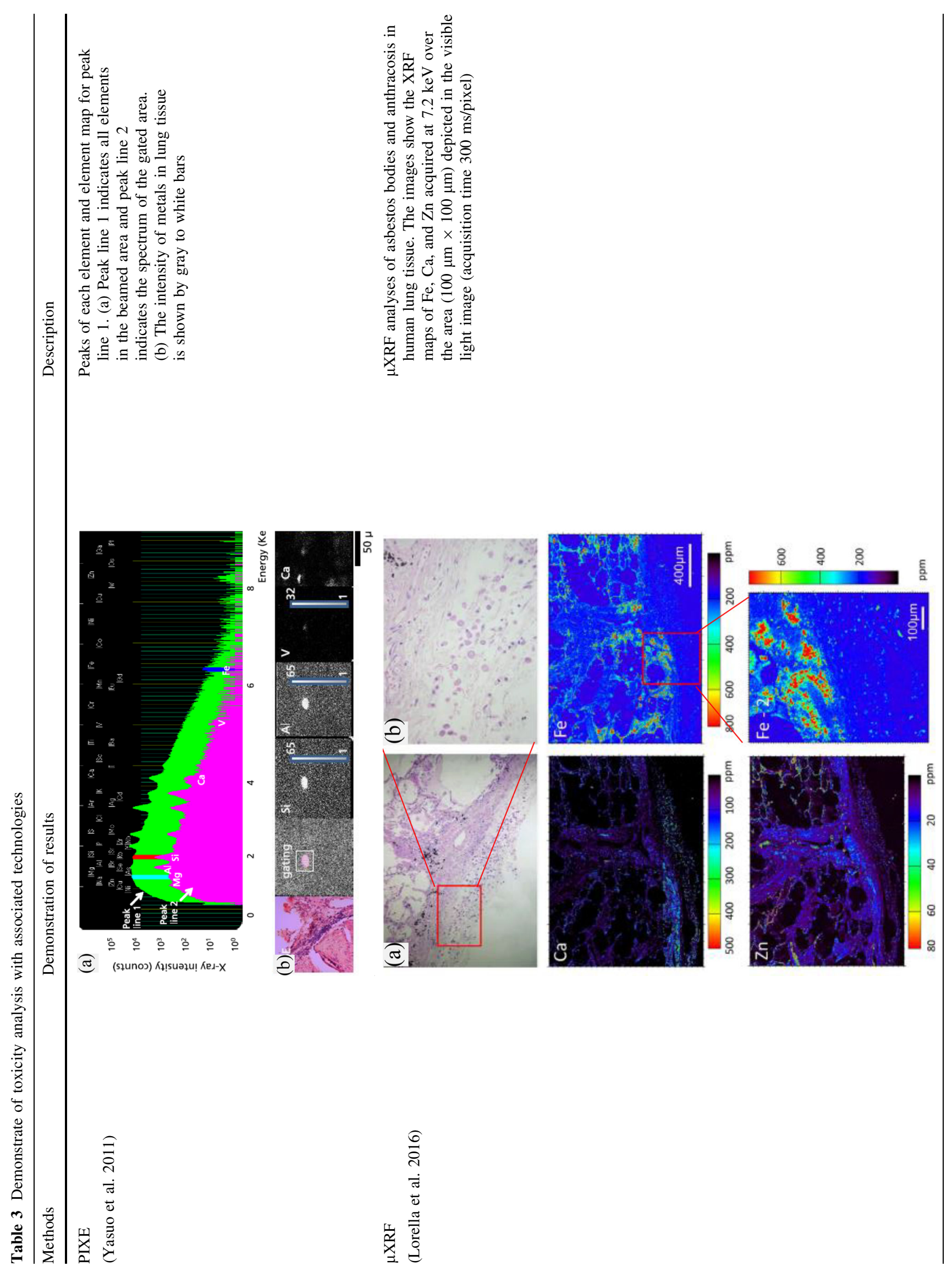




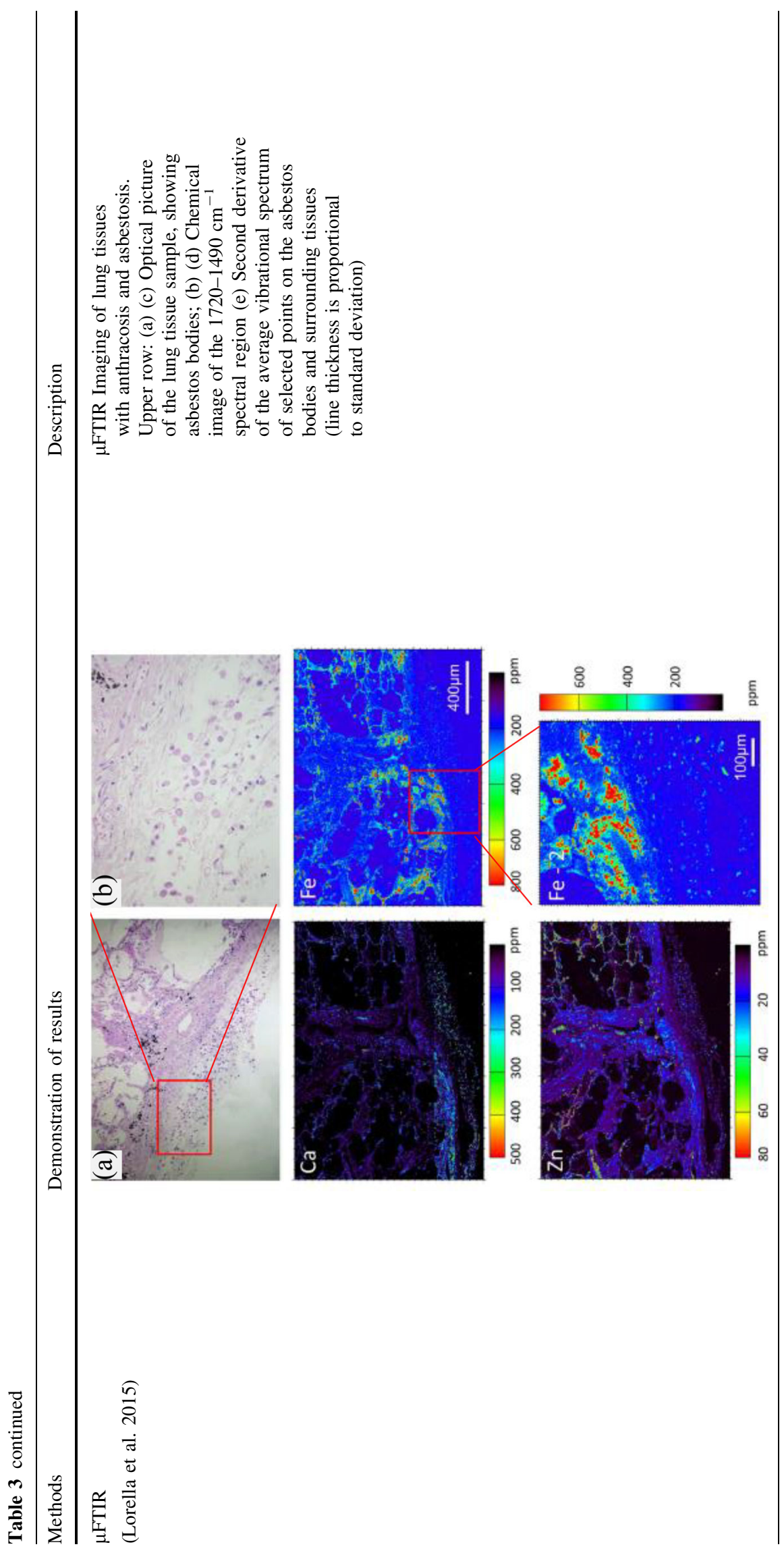




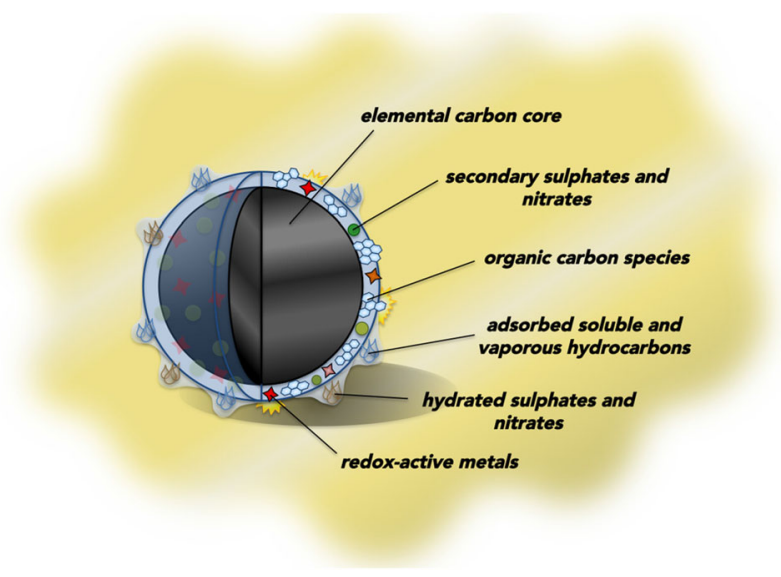

Fig. 10 Complex composition of nano-particulates and coating effects (After Stone et al. 2017)

mechanical generated particulates in complexed underground conditions-would be a substantial contribution to prevent miners from exposing to such hazards.

The formation and transformation of DPMs normally includes several stages: combustion, cooling-dispersiondilution, and particle growth, accompanying with three modes of particulates-nucleation, accumulation and coarse modes-as shown in Fig. 11. Diesel aerosols are, in general, one order of magnitude smaller than other respirable particulates generated in mines through mechanical processes. Their sizes range from $\mathrm{nm}$ to $\mu \mathrm{m}$. Most of the diesel aerosols behavior similar to the gaseous components in underground with a long residence time in the ventilation air. However, the particulates of nucleation mode (less than $0.1 \mu \mathrm{m}$ ), the primary components of which is elemental carbon produced due to incomplete combustion, would be rapidly deposited by Brownian diffusion. These particulates are readily to collide with adjacent particulate to coagulate into large particulates. While particulates go to the region of tailpipe with lower temperature and pressure, they continuously grow due to condensation and coagulation with other semivolatile or volatile organic compounds. The coagulation and evaporation process rapidly diminishe the particulate number of the nucleation mode. With the aging of emitted particulates in air, the particle growth continues via chemical reaction and physical adsorption, and consequently form particulates of accumulate and coarse modes. While the size is larger than $1 \mu \mathrm{m}$, the sedimentation is dominant, and the corresponding residence time shortens. It is reported that particulates between $30 \mathrm{~nm}$ to $1 \mu \mathrm{m}$ tend to have longer atmospheric lifetime because they are less likely to be deposited in either way as shown in Fig. 11 (Kwon et al. 2020).

In addition, the electrical forces a charged airborne dust particle can experience may be of considerable practical importance to lung deposition after inhalation and toxicity alternation. Dust particles could carry varying electric charges after pulverization depending on the characteristics of individual mines. The factors affecting the sign and magnitude of charges on coal dust particles include moisture content, ambient humidity, dust components (e.g., mineral level, sulfate level), process method, and particle size (Johnston et al. 1985; Page 2000; Tessum and Raynor 2017). It is reported that the respirable particles can carry on the order of $10^{2}-10^{6}$ charges per particle that could cause a different dispersion patten in air after it is generated. Most importantly, the surface charge may alternate the surface chemical characteristics through the complex interaction with DPMs in the air that could increase its toxicity. Previous studies demonstrated that the negatively charged dusts would react strongly with scavenger receptors on alveolar macrophages and would activate the generation of reactive oxygen species (ROS) and inflammatory cytokines (Lapp and Castranova 1993; Castranova 1998; Jardin and Wallaert 2012). Since the nano particles tend to deposit more and deeper in the lung, future studies should be conducted focusing on investigating the deposition mechanism of highly-charged nano-dusts and its interaction with lung fluids.

Despite the intensive toxicity by interacting with nanodusts, DPM itself, as another primary contaminant with nano-scale size in underground, especially in metal, nonmetal mines, can cause a severe concern due to its adverse health effects on human body. A substantial body of research addressing the adverse health effect of the DPM and the underlying toxicological mechanisms have been studied, indicating that the long-term or short-term exposure in the environment with high DPM concentration, such as in underground, is responsible for causing respiratory mortality and morbidity (Donaldson 2005; Pope and Dockery 2006; Ayres et al. 2008).

A high number of animal studies starting from 1950s have been carried out to demonstrate that the long-term and short-term exposure to high-concentration DMP concentrations contributes to the increasing risk of lung tumour (Chang and $\mathrm{Xu}$ 2017). As the concentration of DPM is larger than $2.5 \mathrm{mg} / \mathrm{m}^{3}$, all animal studies except for one study have shown a lung tumour response in rats, indicating its positive relationship with DPM exposure (Heinrich et al. 1986). However, Ping et al. summarized in a review paper that although sufficient evidences have been collected in rats test, none of the hamster studies showed the same increasing trend as rats in the risk of lung tumours and only one study involved monkeys, but no lung tumours were found in monkeys after long-term DPM exposure (Chang and Xu 2017). Therefore, it is suggested that more studies should be carried out focusing on the cohort and occupational studies relevant to the potential carcinogenicity of DPM on human bodies. Some epidemiological 


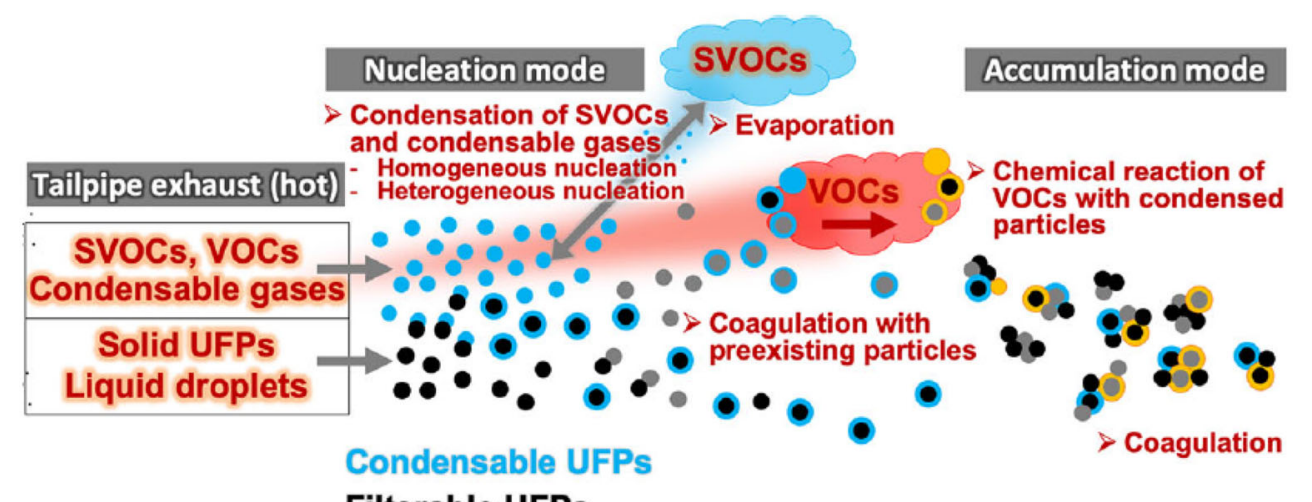

Filterable UFPs

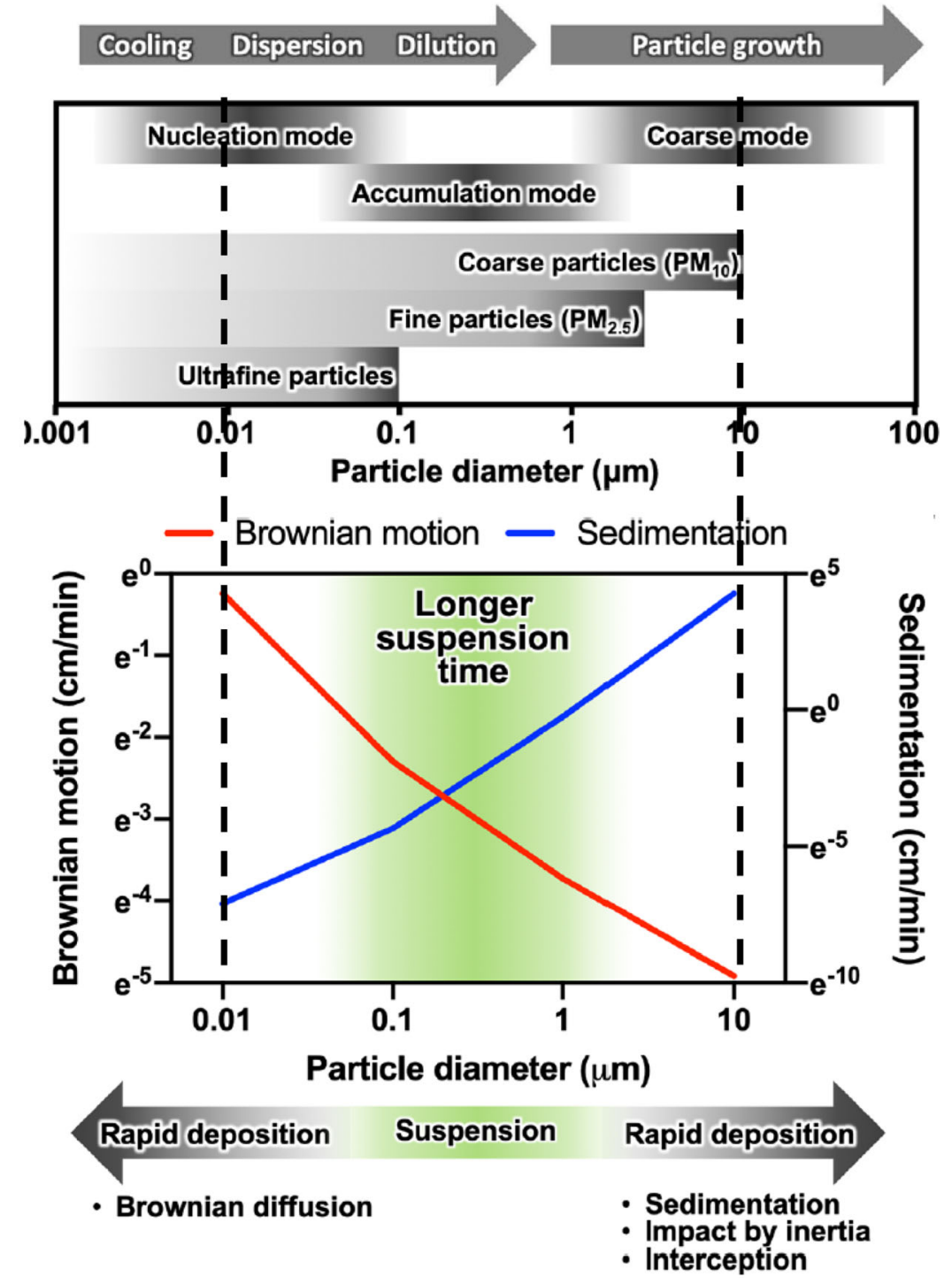

Fig. 11 Demonstration of formation and transformation of DPMs and its residence time in the air (After Kwon et al. 2020)

studies for different job titles have been reported by IARC providing a strong evidence that the DPM exposure could increase the risk of lung tumour for human beings (IARC 2013). The systematic studies of the adverse health effect on coal miners with respect to DPM exposure was reported by NIOSH in 1986 with the title of "Evaluation of the potential health effects of occupational exposure to diesel exhaust in under-ground coal mines", demonstrating a 
strong association between lung cancer and exposure to DPM. Similar study was carried out at 8 U.S. non-metal mines to evaluate the potential influence of DPM exposure on the lung health of 12,315 miners (Attfield et al. 2013). Positive correlation between lung tumour and DPM exposure time was also revealed in this study since the DPM level is generally higher in underground than other industries. Although few studies have been carried out in underground, strong evidences have been found to demonstrate the adverse health effect of DPM exposure. Since the generation source and the mechanism of adverse health effect could be different for DPM compared to nanoscale dusts, more studies should be carried out to further unveil the pathological mechanism and the potential control methodologies for DPM exposure in underground.

\section{Summary, research gaps and recommendations}

Despite nano-particulates are massless and weightless and may invisible in mining environment, their considerable number quantity and dramatically surface area are pivotal to their toxicity and adverse impact on health after being deposited in miners' respiratory tract and transmitted to circulation system. Further studies will be required to answer a few different questions: (1) nano-scale dusts generation sources and rates; (2) their transport and deposition behavior in the prevailing mine environment; (3) pathogenesis and its relation with dust characterization; and (4) effective mitigation methods including monitor and suppression techniques. Number quantity-based monitoring methods should be proposed in mining industry rather than only employing mass-based monitoring. Numerous lab technologies have been developed to quantify the size distribution of collect samples, further studies will be required on mapping the residence time of nano-particulates in a large scale, in particular, considering the environmental moisture and aging of DPMs in underground.

The niche-targeting regulations should be discussed based on the scientific evidence of the mine nano-particulates. Current mass-based regulations of respirable dusts generally consider only the particulates larger than $1 \mu \mathrm{m}$ because the weight accumulation of particulates less than 1 $\mu \mathrm{m}$ is negligible among mechanical generated dusts. A considerable number of nano-particulates and aerosols could be generated through diesel-powered equipment. The combination effects of DPM and existing dusts should be carefully considered while formulating new regulations of respiratory hazard exposure.

Mining operation related nano-dust sources have been summarized in this review. However, the specific particulates properties and size distribution could be dramatically different with various mining related process and ore properties. Various types of dusts should be collected in different coal mines and $\mathrm{M} / \mathrm{NM}$ mines adjacent to different operations. Size distribution and surface functionary characterization are needed to be conducted in the lab. It is necessary to build up the mining operation-based database of dust properties, that would contribute to the dust control and operation optimization.

Acknowledgements We acknowledge the support from NIOSH funding and related resources offered from the Department of Earth and Mineral Engineering at Penn State University for this manuscript.

Author contributions Dr. Shimin Liu conceived of the idea to proof the existence of nano-dusts in mines and its influence. Dr. Long Fan conducted the literature review and drafted the manuscript. All authors supervised the project and discussed the conclusions presented.

Funding This work is financially supported by The National Institute of Occupational Safety and Health (NIOSH) under the contract No. NIOSH-75D30119C05128.

Data availability The datasets used and/or analysed during the current study are available from the corresponding author on reasonable request.

\section{Compliance with ethical standards}

Conflict of interest The author declares that they have no conflict of interest.

Open Access This article is licensed under a Creative Commons Attribution 4.0 International License, which permits use, sharing, adaptation, distribution and reproduction in any medium or format, as long as you give appropriate credit to the original author(s) and the source, provide a link to the Creative Commons licence, and indicate if changes were made. The images or other third party material in this article are included in the article's Creative Commons licence, unless indicated otherwise in a credit line to the material. If material is not included in the article's Creative Commons licence and your intended use is not permitted by statutory regulation or exceeds the permitted use, you will need to obtain permission directly from the copyright holder. To view a copy of this licence, visit http://creativecommons. org/licenses/by/4.0/.

\section{References}

Ackerman JL, Proffit WR, Sarver DM (1999) The emerging soft tissue paradigm in orthodontic diagnosis and treatment planning. Clin Orthod Res 2(2):49-52. https://doi.org/10.1016/j.cub.2015. 10.018

Amponsah-DacostaAnnegam FHJ (1998) Assessment of fugitive dust emissions from an opencast coal mine. J Mine Vent Soc South Africa 51:5-11

Annegarn HJ, Pillay AE, Da Vies JCA, Faure D, Sellschop JPF (1988) PIXE analysis of mineral matter in thin sections of human lung. Nucl Inst Methods Phys Res B 35(3-4):415-419. https:// doi.org/10.1016/0168-583X(88)90303-5

Arias-Andres M, Rojas-Jimenez K, Grossart HP (2019) Collateral effects of microplastic pollution on aquatic microorganisms: an 
ecological perspective. TrAC - Trends Anal Chem 112:234-240. https://doi.org/10.1016/j.trac.2018.11.041

Arnold C, (2016) A scourge returns: black lung in Appalachia. Published online

Attfield MD, Schleiff PL, Lubin JH et al (2012) The diesel exhaust in miners study: a cohort mortality study with emphasis on lung cancer. J Natl Cancer Inst 104(11):869-883

Ayres JG, Borm P, Cassee FR et al (2008) Evaluating the toxicity of airborne particulate matter and nanoparticles by measuring oxidative stress potential-a workshop report and consensus statement. Inhal Toxicol 20(1):75-99

Baker D (2012) Essentials of toxicology for health protection: a handbook for field professionals. Oxford University Press, Oxford

Barone T, Hesse E, Seaman C, et al, (2017) Real-time sizing of airborne coarse coal dust: proceedings of the 16th US Mine ventilation symposium (JF Brune, ed) Society for mining, metallurgy, and exploration. Published online

Blackley DJ, Halldin CN, Laney AS (2018) Continued increase in prevalence of coal workers' pneumoconiosis in the United States, 1970-2017. Am J Public Health 108(9):1220-1222

Blazek C, (2003) The role of chemicals in controlling coal dust emissions. PRB Coal Use Risk Manag Strateg Tactics, Am Coal Counc Michigan. Published online

Block ML, Elder A, Auten RL et al (2012) The outdoor air pollution and brain health workshop. Neurotoxicology 33(5):972-984

Bocskor A, Hunyadi M, Vince D, (2017) National Academies of Sciences, Engineering, and Medicine (2015) The Integration of Immigrants into American Society. Washington, DC: The National Academies Press. 458 pages. Intersect EAST Eur J Soc Polit. 3(3):157-161

Bourdon JA, Saber AT, Jacobsen NR et al (2012) Carbon black nanoparticle instillation induces sustained inflammation and genotoxicity in mouse lung and liver. Part Fibre Toxicol 9(1):5

Cacciottolo M, Wang X, Driscoll I et al (2017) Particulate air pollutants, APOE alleles and their contributions to cognitive impairment in older women and to amyloidogenesis in experimental models. Transl Psychiatry 7(1): 1022

Carpenter MA, Lifshin E, Gauvin R (2002) SEM-EDS quantitative analysis of aerosols $=80 \mathrm{~nm}$ : impacts on atmospheric aerosol characterization campaigns. Microsc Microanal 8(S2):1482-1483

Casanova R, Wang X, Reyes $J$ et al (2016) A voxel-based morphometry study reveals local brain structural alterations associated with ambient fine particles in older women. Front Hum Neurosci 10:495

Cashdollar KL (1996) Coal dust explosibility. J Loss Prev Process Ind 9(1):65-76. https://doi.org/10.1016/0950-4230(95)00050-X

Castranova V (1998) Particulates and the airways: basic biological mechanisms of pulmonary pathogenicity. Appl Occup Environ Hyg 13(8):613-616. https://doi.org/10.1080/1047322X.1998. 10390122

Chang P, Xu G (2017) A review of the health effects and exposureresponsible relationship of diesel particulate matter for underground mines. Int J Min Sci Technol 27(5):831-838. https://doi. org/10.1016/j.ijmst.2017.07.020

Chino H, Hagiwara E, Sugisaki M et al (2015) Pulmonary aluminosis diagnosed with in-air microparticle induced X-ray emission analysis of particles. Intern Med 54(16):2035-2040. https://doi. org/10.2169/internalmedicine.54.4246

Coal R, Dust M, Mines U et al (2018) Monitoring and sampling approaches to assess underground coal mine dust exposures. Natl Acad Press. https://doi.org/10.17226/25111

Cohen RA, Petsonk EL, Rose C et al (2016) Lung pathology in US coal workers with rapidly progressive pneumoconiosis implicates silica and silicates. Am J Respir Crit Care Med 193(6):673-680

Čokić SM, (2018) COMPOSIETSTOF: Evaluatie Van Gezondheidsrisico's En Beschermmaatregelen

Cole CF, Zapert JG (1995) Air quality dispersion model validation at three stone quarries. Natl Stone Assoc Washington, DC, p 14884

Commission E. Definition of a nanomaterial. Published online 2017

Cvetković Ž, Logar M, Rosić A, Ćirić A (2012) Mineral composition of the airborne particles in the coal dust and fly ash of the Kolubara basin (Serbia). Period di Mineral 81(2):205-223

da Silva J (2016) DNA damage induced by occupational and environmental exposure to miscellaneous chemicals. Mutat Res Mutat Res 770:170-182

De Maeyer-Worobiec A,2004. Optimisation and application of different electron probe X-ray microanalysis approaches for the chemical characterisation of individual environmental particles. Published online

Deboudt K, Flament P, Choël M, Gloter A, Sobanska S, Colliex C (2010) Mixing state of aerosols and direct observation of carbonaceous and marine coatings on African dust by individual particle analysis. J Geophys Res Atmos. https://doi.org/10.1029/ 2010JD013921

Denee PB (1972) Mine dust characterization using the scanning electron microscope. Am Ind Hyg Assoc J 33(10):654-660

DiCarlo A, Scheinfein MR, Chamberlin RV (1992) Magnetic force microscopy utilizing an ultrasensitive vertical cantilever geometry. Appl Phys Lett 61(17):2108-2110

Donaldson K, Tran L, Jimenez LA et al (2005) Combustion-derived nanoparticles: a review of their toxicology following inhalation exposure. Part Fibre Toxicol 2:1-14. https://doi.org/10.1186/ 1743-8977-2-10

Doney BC, Blackley D, Hale JM et al (2019) Respirable coal mine dust in underground mines, United States, 1982-2017. Am J Ind Med 62(6):478-485

Doney BC, Halldin C, Drph DB, Bs JMH, Laney AS, Virginia W (2019b) Respirable coal mine dust at surface mines, United States. Am J Ind Med. https://doi.org/10.1002/ajim.23074

Entwistle JA, Hursthouse AS, Marinho Reis PA, Stewart AG (2019) Metalliferous mine dust: human health impacts and the potential determinants of disease in mining communities. Curr Pollut Rep 5(3):67-83. https://doi.org/10.1007/s40726-019-00108-5

Fan L, Liu S (2017) A conceptual model to characterize and model compaction behavior and permeability evolution of broken rock mass in coal mine gobs. Int J Coal Geol 172:60-70. https://doi. org/10.1016/j.coal.2017.01.017

Fan L, Liu S (2019a) Fluid-dependent shear slip behaviors of coal fractures and their implications on fracture frictional strength reduction and permeability evolutions. Int $\mathrm{J}$ Coal Geol 212(July):103235. https://doi.org/10.1016/j.coal.2019.103235

Fan L, Liu S (2019b) Evaluation of permeability damage for stressed coal with cyclic loading: an experimental study. Int J Coal Geol 216(November):103338. https://doi.org/10.1016/j.coal.2019. 103338

Frisbie CD, Rozsnyai LF, Noy A, Wrighton MS, Lieber CM (1994) Functional group imaging by chemical force microscopy. Science 265(5181):2071-2074

Fujihira M, Morita Y (1994) Atomic force microscopy and friction force microscopy of chemically modified surfaces. J Vac Sci Technol B Microelectron Nanom Struct Process Meas Phenom 12(3):1609-1613

Gasparotto J, Chaves PR, da Boit MK et al (2018) Obese rats are more vulnerable to inflammation, genotoxicity and oxidative stress induced by coal dust inhalation than non-obese rats. Ecotoxicol Environ Saf 165(August):44-51. https://doi.org/10. 1016/j.ecoenv.2018.08.097 
Ghose MK, Majee SR (2007) Characteristics of hazardous airborne dust around an Indian surface coal mining area. Environ Monit Assess 130(1-3):17-25. https://doi.org/10.1007/s10661-0069448-6

Gianoncelli A, Rizzardi C, Salomon D, Canzonieri V, Pascolo L (2018) Nano-imaging of environmental dust in human lung tissue by soft and hard X-ray fluorescence microscopy. Spectrochim Acta Part B At Spectrosc 147:71-78. https://doi.org/10. 1016/j.sab.2018.05.019

Gibson H, Vincent JH (1980) On the impaction of airborne coarse dust into the eyes of human subjects. Ann Occup Hyg 23(1):35-45. https://doi.org/10.1093/annhyg/23.1.35

Graczyk H, Riediker M (2019) Occupational exposure to inhaled nanoparticles: are young workers being left in the dust? J Occup Health 61(5):333-338. https://doi.org/10.1002/1348-9585.12056

Gresh RE, Ashley JD, Energy L, (1994) Reducing Enclosed Cab Drill Operator's Respirable Dust Exposure At Surface Coal Operation With A Retrofitted Filtration And Pressurization System AB Cecala and JA . Organiscak Natl Inst for Occuptnl Sfty and Health Pittsburgh, PA WA Heitbr. Published online

Hall NB, Blackley DJ, Halldin CN, Laney AS, Hall NB (2019) Current review of pneumoconiosis among US coal miners. Curr Env Health Rep 6(3):137-147. https://doi.org/10.1007/s40572019-00237-5

He X, Shen H, Chen Z et al (2017) Element-based prognostics of occupational pneumoconiosis using micro-proton-induced $X$-ray emission analysis. Am J Physiol Lung Cell Mol Physiol 313(6):L1154-L1163. https://doi.org/10.1152/ajplung.00009. 2017

Heinrich U, Muhle H, Takenaka S et al (1986) Chronic effects on the respiratory tract of hamsters, mice and rats after long-term inhalation of high concentrations of filtered and unfiltered diesel engine emissions. J Appl Toxicol 6(6):383-395

Hesse E, Mc Call DS, Ulanowski Z, Stopford C, Kaye PH (2009) Application of RTDF to particles with curved surfaces. J Quant Spectrosc Radiat Transf 110(14-16):1599-1603

Heusinkveld HJ, Wahle T, Campbell A et al (2016) Neurodegenerative and neurological disorders by small inhaled particles. Neurotoxicology 56:94-106

Huggins CW, Meyers GT, (1986) Particle size distribution of quartz and other respirable dust particles collected at metal mines, nonmetal mines, and processing plants. Published online

IARC, (2013) Diesel and gasoline engine exhausts and some nitroarenes, IARC monographs on the evaluation of carcinogenic risks to humans. Published online

Jardin C, Wallaert B (2012) Silicosis and coal worker's pneumoconiosis. Clin Respir Med Fourth Ed 108:637-644. https://doi.org/ 10.1016/B978-1-4557-0792-8.00051-9

Jiang H, Du C, Dong J (2017) Investigation of rock cutting dust formation and suppression using water jets during mining. Powder Technol 307:99-108. https://doi.org/10.1016/j.powtec. 2016.11.029

Johnson CA, Chern M, Nguyen TT, Dennis AM, Goldfarb JL (2019) Ligands and media impact interactions between engineered nanomaterials and clay minerals. NanoImpact. https://doi.org/10. 1016/j.impact.2019.01.004

Johnston AM, Vincent JH, Jones AD (1985) Measurements of electric charge for workplace aerosols. Ann Occup Hyg 29(2):271-284. https://doi.org/10.1093/annhyg/29.2.271

Jones T, Morgan A, Richards R (2003) Primary blasting in a limestone quarry: physicochemical characterization of the dust clouds. Mineral Mag 67(2):153-162. https://doi.org/10.1180/ 0026461036720092

Kabata-Pendias A (2000) Trace elements in soils and plants. CRC Press. https://doi.org/10.1017/CBO9781107415324.004
Kasahara M, Shinoda K, Yoshida K, Takahashi K (1993) 45 O 05 Characterization of atmospheric aerosol based on SEM-EDX analysis of individual particle. J Aerosol Sci 24:S585-S586

Kasparian J, Frejafon E, Rambaldi P et al (1998) Characterization of urban aerosols using SEM-microscopy, X-ray analysis and Lidar measurements. Atmos Environ 32(17):2957-2967

Kim JW, Park S, Lim CW, Lee K, Kim B (2014) The role of air pollutants in initiating liver disease. Toxicol Res 30(2):65

Kioumourtzoglou M-A, Schwartz JD, Weisskopf MG et al (2015) Long-term PM2.5 exposure and neurological hospital admissions in the northeastern United States. Environ Health Perspect 124(1):23-29

Kreyling WG (1990) Interspecies comparison of lung clearance of “ insoluble" particles. J Aerosol Med. https://doi.org/10.1089/jam. 1990.3.Suppl_1.S-93

Kreyling WG, Semmler-Behnke M, Takenaka S, Moller W (2012) Differences in the biokinetics of inhaled nano-versus micrometer-sized particles. Acc Chem Res 46(3):714-722

Kreyling WG, Holzwarth U, Haberl N et al (2017) Quantitative biokinetics of titanium dioxide nanoparticles after intratracheal instillation in rats: part 3. Nanotoxicology 11(4):454-464

Kwon H-S, Ryu MH, Carlsten C (2020) Ultrafine particles: unique physicochemical properties relevant to health and disease. Exp Mol Med. https://doi.org/10.1038/s12276-020-0405-1

Lapp NL, Castranova V (1993) How silicosis and coal workers' pneumoconiosis develop-a cellular assessment. Occup Med $8(1): 35-56$

León-Mejia G, Machado MN, Okuro RT et al (2018) Intratracheal instillation of coal and coal fly ash particles in mice induces DNA damage and translocation of metals to extrapulmonary tissues. Sci Total Environ 625:589-599

Liu T, Liu S (2020) The impacts of coal dust on miners' health: a review. Environ Res 190:109849. https://doi.org/10.1016/j. envres.2020.109849

Liu Y, Ferralis N, Bryndzia LT, Grossman JC (2016) Genomeinspired molecular identification in organic matter via Raman spectroscopy. Carbon N Y 101:361-367

Maivald P, Butt HJ, Gould SAC et al (1991) Using force modulation to image surface elasticities with the atomic force microscope. Nanotechnology 2(2):103

Mani U, Prasad AK, Kumar VS et al (2007) Effect of fly ash inhalation on biochemical and histomorphological changes in rat liver. Ecotoxicol Environ Saf 68(1):126-133

Martin Y, Wickramasinghe HK (1987) Magnetic imaging by force microscopy with 1000 Åresolution. Appl Phys Lett 50(20):1455-1457

McCunney RJ, Morfeld P, Payne S (2009) What component of coal causes coal workers pneumoconiosis? J Occup Environ Med 51(4):462-471

Menezes APS, Da Silva J, Roloff J et al (2013) Baccharis trimera (less.) DC as genotoxicity indicator of exposure to coal and emissions from a thermal power plant. Arch Environ Contam Toxicol. 65(3):434-441. https://doi.org/10.1007/s00244-0139918-0

Menezes APS, Da Silva J, Rossato RR et al (2015) Genotoxic and biochemical changes in Baccharis trimera induced by coal contamination. Ecotoxicol Environ Saf 114:9-16. https://doi.org/ 10.1016/j.ecoenv.2015.01.001

Moreno T, Trechera P, Querol X et al (2019) Trace element fractionation between PM10 and PM2. 5 in coal mine dust: Implications for occupational respiratory health. Int $\mathrm{J}$ Coal Geol 203:52-59

Muleski G, Dobson R, Connery K, (1991) Review of Surface Coal Mining Emission Factors. https://www.osti.gov/biblio/80603

Neubauer G, Erickson A, Williams CC, Kopanski JJ, Rodgers M, Adderton D (1996) Two-dimensional scanning capacitance 
microscopy measurements of cross-sectioned very large scale integration test structures. J Vac Sci Technol B Microelectron Nanom Struct Process Meas Phenom 14(1):426-432

NIOSH, (2019) Dust control handbook for industrial minerals mining and processing, 2nd Edition. Published online

Oberbek P, Kozikowski P, Czarnecka K, Sobiech P, Jakubiak S, Jankowski T (2019) Inhalation exposure to various nanoparticles in work environment-contextual information and results of measurements. J Nanopart Res. https://doi.org/10.1007/s11051019-4651-x

Oberdörster G, Oberdörster E, Oberdörster J (2005) Nanotoxicology: an emerging discipline evolving from studies of ultrafine particles. Environ Health Perspect 113(7):823-839. https://doi. org/10.1289/ehp.7339

Oberdörster G, Elder A, Rinderknecht A (2009) Nanoparticles and the brain: cause for concern? J Nanosci Nanotechnol 9(8):4996-5007

Ogasawara N, Sasaki M, Itoh Y (2011) Rebamipide suppresses TLR?TBK1 signaling pathway resulting in regulating IRF3/7. J Clin Biochem Nutr 48(2):154-160. https://doi.org/10.3164/ jcbn. 10

Organiscak JA (2013) Examination of water spray airborne coal dust capture with three wetting agents. Trans Soc Mining Metall Explor Inc 334(1) 427

Organiscak JA, Page SJ (2005) Development of a dust collector inlet hood for enhanced surface mine drill dust capture. Int J Surf Min Reclam Environ 19(1):12-28

Page SJ (2000) Relationships between electrostatic charging characteristics, moisture content, and airborne dust generation for subbituminous and bituminous coals. Aerosol Sci Technol 32(4):249-267. https://doi.org/10.1080/027868200303605

Painter PC, Snyder RW, Starsinic M, Coleman MM, Kuehn DW, Davis A (1981) Concerning the application of FT-IR to the study of coal: a critical assessment of band assignments and the application of spectral analysis programs. Appl Spectrosc 35(5):475-485

Pascolo L, Borelli V, Canzonieri V et al (2015) Differential protein folding and chemical changes in lung tissues exposed to asbestos or particulates. Sci Rep 5:1-13. https://doi.org/10.1038/ srep12129

Pascolo L, Gianoncelli A, Rizzardi C et al (2016) Focused X-Ray histological analyses to reveal asbestos fibers and bodies in lungs and pleura of asbestos-exposed subjects. Microsc Microanal 22(5):1062-1071. https://doi.org/10.1017/S1431927616011685

Pauw BR, Kästner C, Thünemann AF (2017) Nanoparticle size distribution quantification: results of a small-angle X-ray scattering inter-laboratory comparison. J Appl Crystallogr 50(5):1280-1288. https://doi.org/10.1107/S160057671701010X

Persch G, Born C, Engelmann H, Koehler K, Utesch B (1993) Applications of scanning probe microscopies in technology and manufacturing. Scanning 15(5):283-290

Pope CA, Dockery DW (2006) Health effects of fine particulate air pollution: lines that connect. J Air Waste Manag Assoc 56(6):709-742. https://doi.org/10.1080/10473289.2006.10464485

Prata JC (2018) Airborne microplastics: consequences to human health? Environ Pollut 234:115-126. https://doi.org/10.1016/j. envpol.2017.11.043

Reed WR, Westman EC, Haycocks C, (2001) An improved model for estimating particulate emissions from surface mining operations in the eastern United States. In: securing the future, international conference on mining and the environment, proceedings, The Swedish Mining Association, SkellefteÂ, Sweden (p 693-702)

Richards J, Brozell T, (2001) Compilation of national stone, sand and gravel association sponsored emission factor and air quality studies 1991-2001. Arlington, Virginia Natl Stone, Sand Gravel Assoc Published online
Sapko MJ, Cashdollar KL, Green GM (2007) Coal dust particle size survey of US mines. J Loss Prev Process Ind 20(4-6):616-620. https://doi.org/10.1016/j.jlp.2007.04.014

Sarver E, (2018) Further characterizing respirable coal mine particulates: submicron particles, metals and diesel exhaust. Alpha Found. Published online

Schins RPF, Borm PJA (1999) Mechanisms and mediators in coal dust induced toxicity: a review. Ann Occup Hyg 43(1):7-33

Semmler-Behnke M, Lipka J, Wenk A et al (2014) Size dependent translocation and fetal accumulation of gold nanoparticles from maternal blood in the rat. Part Fibre Toxicol 11(1):33

Smith A (1986) Respirable Dust Generation. Oxford Univ. 1986;XXX:60. https://books.googleusercontent.com/books/con tent?req=AKW5QaeZb8cCzW14I5L5LPrBClSJJgAXxJx ciOIe9Nj7iGbkyHgkrSKm9_f_eQZBmoPJ-LQQeri7eZdQbi BrACMUvmaqh8k5jh-CyOT97vEdjCbC9lZkltWgy565Zn Sag8m-cDJYlEGvgQupUrfpQ872PWSk2UuDKmw2cwbLtqk2HWF21P_ywlLi4L6KmLa7khGsKsla

Smith H, (1994) Human respiratory tract model for radiological protection. ICRP Publ 66. Published online

Stewart A, Hursthouse A (2018) Environment and human health: the challenge of uncertainty in risk assessment. Geosciences 8(1):24

Stone V, Miller MR, Clift MJD et al (2017) Nanomaterials versus ambient ultrafine particles: an opportunity to exchange toxicology knowledge. Environ Health Perspect 125(10):1-17. https:// doi.org/10.1289/EHP424

Sugawara Y, Fukano Y, Uchihashi T et al (1994) Atomic force microscopy studies of contact-electrified charges on silicon oxide film. J Vac Sci Technol B Microelectron Nanom Struct Process Meas Phenom 12(3):1627-1630

Sun Z, Hong J, Yang D, Liu G (2007) Effects of coal dust contiguity on xerophthalmia development. Cutan Ocul Toxicol 26(3):257-263

Sun Z, Hong J, Liu Z, Jin X, Gu C (2009) Coal dust contiguityinduced changes in the concentration of TNF- and NF- B p65 on the ocular surface. Ocul Immunol Inflamm 17(2):76-82. https:// doi.org/10.1080/09273940802650380

Tessum MW, Raynor PC (2017) Effects of spray surfactant and particle charge on respirable coal dust capture. Saf Health Work 8(3):296-305. https://doi.org/10.1016/j.shaw.2016.12.006

Wang QC, Luo YH, (2009) Application SEM to analysis formation characteristic of soot aerosol emitted from lump-coal combustion in fixed-bed. In: 2009 Asia-pacific power and energy engineering conference (pp 1-4)

White EW, DeNee PB (1972) Characterization of coal mine dust by computer processing of scanning electron microscope information. Ann N Y Acad Sci 200(1):666-675

Yang X, Elsworth D, Zhou J, Nie A, Liu L (2020) A new approach to evaluate the particle size distribution from rock drilling: double peak characteristic analysis. Geomech Geophys Geo-Energy GeoResources 6(2):1-9. https://doi.org/10.1007/s40948-020-00161-1

Yoo MJ, Fulton TA, Hess HF et al (1997) Scanning single-electron transistor microscopy: imaging individual charges. Science 276(5312):579-582

Zhao J, Suárez G, Tran N, Puntes V, Riediker M (2019) Coating aerosolized nanoparticles with low-volatile organic compound (LVOC) vapors modifies surface functionality and oxidative reactivity. NanoImpact 14:100150. https://doi.org/10.1016/j. impact.2019.100150

Zhao W, Wang K, Cheng Y, Liu S, Fan L (2020) Evolution of gas transport pattern with the variation of coal particle size: Kinetic model and experiments. Powder Technol 367:336-346. https:// doi.org/10.1016/j.powtec.2020.03.061

Zimmer RA, Lueck SR, Page SJ (1987) Optimization of overburden drill dust control systems on surface coal mines. Int J Surf Min Reclam Environ 1(2):155-157 